\title{
TAGÁLLAMI ÉRDEKEK, BELSŐ PIACI SZABADSÁGOK ÉS AZ EURÓPAI BÍRÓSÁG JOGGYAKORLATA**
}

https://doi.org/10.51783/ajt.2021.1.02

Jelen tanulmány célja annak bemutatása, hogy az Európai Unió belső piaci szabadságai mennyiben gátolják meg a tagállamokat saját nemzeti érdekeik érvényesítésében. Ezenkívül azzal a kérdéssel is foglalkozik, hogy az EU jogi feltételrendszere mennyiben alkalmas a tagállamok különbözö társadalmi, kulturális és politikai intézkedéseinek elfogadására. Az irás törekszik annak elemzésére is, hogy az Európai Unió Bíróságának a belső piaci szabadságok körében, a nem harmonizált jogterületeken alkalmazott jogértelmezési keretrendszere mennyiben alkalmas a partikuláris, egyéni magatartást tanúsító tagállamok által bevezetett korlátozások jogszerüségének elemzésére. Más jogirodalmi véleményekkel összhangban a tanulmány arra a következtetésre jut, hogy az Európai Unió Bírósága által a négy szabadság túlságosan kiterjesztően meghatározott hatályát korlátozni kellene abból a célból, hogy legitim tagállami közpolitikai célok jobban érvényesülhessenek. A tanulmány másrészről azzal az elhatárolási nehézséggel is számot vet, amely a legitim tagállami közpolitikai intézkedések és a protekcionizmus között áll fenn.

A tanulmány a terjedelmi korlátok és a belső piaci jog sokrétüsége miatt csak néhány közös, alapvető jellemzőt mutat be, a belső piaci jogon belüli egyes jogterületek vagy szabadságok feltérképezése külön tanulmányok tárgyát képezhetné.

\section{BEVEZETÉS}

A közös piac, amelyet később belső piacra neveztek át, az 1950-es évektől kezdve a tagállamok közötti gazdasági integráció sarokköve volt. Ez az a bázis, amelyre az európai nemzetek az egymás közötti további integrációt építik fel. ${ }^{1}$ Mára megkérdő-

* PhD, tudományos munkatárs, Társadalomtudományi Kutatóintézet Lendület-HPOPs Regulatory Change kutatócsoport, 1097 Budapest, Tóth Kálmán utca 4.; adjunktus, Eötvös Loránd Tudományegyetem Állam- és Jogtudományi Kar, 1053 Budapest, Egyetem tér 1-3. E-mail: papp. monika@tk.hu.

"* A kéziratot a szerző 2020 márciusában nyújtotta be a szerkesztőségnek. A tanulmány korábbi változata megjelent: Mónika PAPP: „Member State Interests and EU Internal Market Law” in Marton VARJU (szerk.): Between Compliance and Particularism: Member State Interests and European Union Law (Cham: Springer 2019) 103-127.

1 Hermann-Josef BlankE: „The economic constitution of the European Union” in Hermann-Josef Blanke - Stelio Mangiameli (szerk.): The European Union after Lisbon (Berlin: Springer Verlag 2012) 369-419. https://doi.org/10.1007/978-3-642-19507-5_15; Wouter DeVRoE - Pieter VAN CLEYNEnBReugeL: „Observations on economic governance and the search for a European economic constitution" in Dagmar SchIEK - Ulrike LIEBERT - Hildegard SchNeIDER (szerk.): European eco- 
jelezhetetlen lett a korábban különálló nemzeti gazdaságok közötti integráció. A torzítatlan verseny elvére épülő áruk, személyek, szolgáltatások és később tőke szabad áramlása megteremtette a gazdasági és szociális koordináció és később az eurózóna államai közötti gazdasági és monetáris unió bevezetésének alapjait. ${ }^{2}$

A tanulmány a tagállamok közötti gazdasági integrációnak kizárólag a belső piaci szabadságok értelmezésére vonatkozó bírósági joggyakorlatával foglalkozik. Az elemzés módszertana jogi empíriával alátámasztott jogirodalmi áttekintés, amely a jog kontextuális valóságára is szeretne rámutatni. ${ }^{3}$

Jelen tanulmány célja annak bemutatása, hogy az Európai Unió belső piaci szabadságai mennyiben gátolják meg a tagállamokat saját nemzeti érdekeik érvényesítésében. Ezenkívül az a kérdés is felmerül, hogy az EU jogi feltételrendszere mennyiben alkalmas a tagállamok különböző társadalmi, kulturális és politikai intézkedéseinek elfogadására. Az írás törekszik annak elemzésére, hogy az Európai Unió Bíróságának a belső piaci szabadságok körében, a nem harmonizált jogterületeken alkalmazott jogértelmezési keretrendszere mennyiben alkalmas a partikuláris, egyéni magatartást tanúsító tagállamok által bevezetett korlátozások jogszerüségének elemzésére. Más jogirodalmi véleményekkel összhangban a tanulmány arra a következtetésre jut, hogy az Európai Unió Bírósága által a négy szabadság túlságosan kiterjesztően meghatározott hatályát korlátozni kellene azért, hogy a legitim tagállami közpolitikai célok érvényesítése nagyobb teret kaphasson. A tanulmány másrészről azzal az elhatárolási nehézséggel is számot vet, amely a legitim tagállami közpolitikai intézkedések és a protekcionizmus között áll fenn.

A tanulmány a terjedelmi korlátok és a belső piaci jog sokrétűsége miatt csak néhány közös, alapvető jellemzőt vizsgál, a belső piaci jogon belüli egyes jogterületek vagy szabadságok feltérképezése külön tanulmányok tárgyát képezhetné. ${ }^{4}$

\section{A KONTEXTUS}

A piac nem önállóan alakul ki, egy adott társadalmi és politikai összefüggésben teremthető csak meg. Polányi Károly az 1940-es években megfogalmazta, hogy az államipiaci kapcsolatok a társadalomban gyökereznek. ${ }^{5}$ Álláspontja szerint a piac különálló elemzése hibás, mivel a piac társadalmi, kulturális és gazdasági kontextusban léte-

nomic and social constitutionalism after the Treaty of Lisbon (Cambridge: Cambridge University Press 2011) 96-122., 106-107. https://doi.org/10.1017/CBO9780511835193.007.

2 Az Európai Unió Bíróságának értelmezésében a belső piac a négy gazdasági szabadság és a verseny elveire épül. C-300/89. sz. Bizottság kontra Tanács ügyben 1991. június 11-én hozott ítélet, EU:C:1991:244, 14-16. pontok. A verseny az európai integráció létrehozásának előfeltétele.

3 Mivel az elemzés kerete a belső piaci szabadságok alapszerződési rendelkezéseinek európai bírósági értelmezése, ezért a tanulmány nem tér ki a belső piac már harmonizált szabályainak, a másodlagos jognak az értelmezésére, és nem foglalkozik a belső piaci versenyjogi rendelkezések értelmezésének különálló kérdéseivel sem.

4 Lásd az MTA TK Lendület-HPOPs Kutatócsoport jogi térképezési jelentéseit: https://hpops.tk.mta.hw/jogi.

5 Karl PoLANYI: The great transformation: the political and economic origins of our time (Boston, MA: Beacon Press [1944] 2001). 
zik. Ő hívta fel a figyelmet az ipari kapitalizmus belső instabilitására, valamint figyelmeztetett arra, hogy a pénz, föld és munka áruvá tétele a kapitalizmus válságát hozhatja létre, és a piacokat megkérdőjelező mozgalmak kialakulásához járulhat hozzá. ${ }^{6}$

A tagállamok, mint a Szerződések urai, elismerték az európai piaci integráció jogi és közpolitikai építményének hiányosságait és az uniós kompetenciákat további nem piaci hatáskörökkel bővítették, ezzel fejezve ki, hogy együttműködésük meghaladta a hagyományos piaci integrációt, és kiterjed például a kultúrára, szociális védelemre, valamint a környezetvédelemre is. A Lisszaboni Szerződés által bevezetett hatályos szerződési rendszerben már kifejeződik a belső piac beágyazottsága abban a szélesebb célrendszerben, amelyet a magas versenyképességű szociális piacgazdaság jelent és az Unió által elérni kívánt célok gazdag listája. ${ }^{7}$ Másrészről az Uniónak is van egy olyan kiterjedt kötelezettsége, hogy az egyéb célokat és értékeket integrálja gazdaságpolitikájába. ${ }^{8}$ Az EUMSZ 7. cikke szerint például az EU köteles valamennyi célkitűzését figyelembe véve biztosítani a különböző politikái és tevékenységei összhangját.

Az EU belső piacának megalkotása, több évtizedes politikai és jogi fejlődés ellenére, még mindig nem valósult meg. A tagállamok számos fontos tárgykörben kompetenciával rendelkeznek, az EU jogharmonizáció nem teljes körü, valamint számos kivétel és opt-out ad lehetőséget az eltérésre attól az ideális állapottól, amely egy homogén jogi és gazdasági térséget, jórészt egységes tevékenységi térséget jellemez. ${ }^{9} \mathrm{~A}$ másodlagos jogalkotás révén az EU-intézmények felhatalmazottak a kereskedelem legfontosabb korlátainak felszámolására és olyan közös szabályok megalkotására, amelyeknek valódi célja a belső piac feltételeinek javítása. ${ }^{10} \mathrm{Az}$ uniós intézmények rendelkezésére álló eszközök széles körủek, a kemény jogi eszközök-

6 Polányi elméletét kritikusan elemzi Christian Joerges: „Europe’s economic constitution in crisis and the emergence of a new constitutional constellation” Zentra Working Paper in Transnational Studies 06/2012.

7 Lásd az EUSZ 2. cikkét az Unió értékeiről és 3. cikkét céljairól.

8 Lásd az EUMSZ 8. cikkét az egyenlőtlenségek kiküszöbölésére irányuló célkitűzésről, 9. cikkét a foglalkoztatás magas szintjének előmozdításáról, a megfelelő szociális védelem biztosításáról, a társadalmi kirekesztés elleni küzdelemről, az oktatás, képzés és emberi egészség magas szintű védelmének követelményéről, az EUMSZ 12. cikkét a fogyasztóvédelmi követelmények integrációjáról, a 14. cikket az általános gazdasági érdekủ szolgáltatásokról.

9 Lásd ebben az értelemben a Bíróság C-15/81. sz. Gaston Schul-ügyben 1982. május 5-én hozott ítéletét, EU:C:1982:135, 33. pont: A közös piacnak Bíróság által a konzisztens döntéseiben megadott koncepciója a Közösségen belüli összes kereskedelemkorlátozás felszámolását célozza azért, hogy a tagállami piacok egy olyan belső piaccá olvadjanak össze, amelynek feltételei amennyire csak lehetséges, megegyezzenek egy valódi belső piac feltételeivel. A Bizottság és a jogirodalom is gyakran használja a „level playing field” kifejezést. A „level playing field” elfogadott magyar fordítása „egyenlő feltételek” vagy „egyenlő versenyfeltételek”. Az egyenlő versenyfeltételek megvalósítása azonban inkább csak elméleti cél, hiszen az elsődleges jog számos tagállami közpolitikai érdek védelmét lehetővé teszi a tagállamok számára, valamint a belső piaci jogharmonizáció is korlátozott.

${ }^{10}$ Lásd ebben az értelemben a C-376/98. sz. Németország kontra Európai Parlament és Tanács ügyben 2000. október 5-én hozott ítéletet, EU:C:2000:544, 84. pont: „A Szerződés 100a. cikke alapján elfogadott jogszabály céljának ténylegesen a belső piac megteremtése és működése feltételei javításának kell lennie. Ha a nemzeti jogszabályok közötti eltérések, az alapvető szabadságok korlátozásának elméleti veszélye, vagy a verseny esetlegesen ebből származó torzulásának egyszerū megállapítása elegendő lenne a 100a. cikk jogalapként történő megjelöléséhez, a jogalap bírósági felülvizsgálata értelmét vesztené. A Bíróságot ez akadályozná az EK-szerződés 164. cikke (jelenleg 
től kezdve a puha jogi eszközökön át, az egységes jogot létrehozó teljes jogharmonizációtól a minimum és részleges, célzott jogharmonizáción keresztül. ${ }^{11}$ A gyakorlatban az uniós jogalkotó a jogi eszközök megválasztásán keresztül akár elég jelentős közpolitikai, szabályozási és más típusú tagállami különbségek megtartásához, tolerálásához is hozzájárulhat. ${ }^{12} \mathrm{~A}$ meghatározatlan jogi fogalmak, nyitott tartalmú jogi szabályok és az elvek felhasználásával elfogadott szabályok mind-mind az eltérő jogi, politikai, gazdasági és társadalmi háttérrel rendelkező tagállamok által kötött kompromisszumok jogi megnyilvánulásai lehetnek.

Ezenkívül a delegált szabályalkotás is lehetőséget biztosíthat az alacsonyabb szintủ jogalkotási szereplőknek, hogy a szakértelmükből fakadó jogi szabályokat hozzanak. Ehhez hasonlóan a nyitott, szélesen meghatározott jogi fogalmak lehetővé tehetik a tagállamoknak, hogy a végrehajtás során nemzeti preferenciáikat érvényesítsék. Az EU-jogban ismert cselekvési tervek szintén döntési lehetőséget kínálnak a tagállamok számára, hogy a célt milyen fokozatokkal és milyen közbenső megvalósítási határidőkkel érik el. ${ }^{13}$

Ezen túl az EU jogi normáinak végrehajtása általában tagállami szinten valósul meg, abból a célból, hogy a helyi megfelelést biztosítsák, és azért is, mert ez lehetőséget nyújt a piacok müködését illető helyi szakértelem integrációjára a végrehajtás során. A tagállami különbségek úgy is manifesztálódhatnak, hogy a belső piaci szabályok hálózatos igazgatásának keretében (network governance) a helyi szervek delegált szabályalkotási vagy végrehajtási funkciókat kaphatnak. ${ }^{14}$

Az EU belső piaci jogalapja is visszatükrözi a tagállamok szociális, gazdasági és jogi különbözőségét, mivel az EUMSZ 4. cikk (2) bekezdése a belső piacot a megosztott hatáskörök közé sorolja, és az EUMSZ 114. cikke minősített többséghez köti a döntéshozatalt, amely a tagállamok között politikai kompromisszumokat feltételez.

EK 220. cikk) szerinti feladata ellátásában, ami a jog tiszteletben tartásának biztosítása a Szerződés értelmezése és alkalmazása során.”

11 A „kemény” és „puha jogi eszközök” a „hard” és „soft law” magyar fordításai. A kemény jogi eszközök kifejezésen egyszerűen kötőerővel rendelkező jogi normákat értünk, a puha jogi eszközöknél a kötőerő hiányában is joghatások keletkeznek az adott jogi eszközből. A soft law magyar irodalmából lásd különösen: VÁRNAY Ernő - TóTH Tihamér: „Közlemények az uniós jogban” Állam-és Jogtudomány 2009/4, 417-472. és LÁNcos Lea Petra: „Az uniós soft law kutatásának főbb eredményei és aktuális kihívásai” Iustum Aequum Salutare 2018/4. 55-68.

12 Mark Dawson - Alieza Durana: „Modes of flexibility: framework legislation v »soft «law” in Andrea Отт and Ellen Vos (szerk.): Between flexibility and disintegration in EU law (Cheltenham: Edward Elgar Publishing 2017) 92-117. https://doi.org/10.4337/9781783475896.00011.

13 Ennek legjobb példái az éghajlatváltozás kapcsán hozott szakpolitikai célkitűzések, amelyek az EU egészének írnak elő például meghatározott százalékú dekarbonizációs kötelezettséget, de a tagállamok szintjére lebontva ez más és más szakpolitikai célkitüzést jelent.

14 Tobias BAcH - Eva Ruffing: „The multi-level administration of the EU. Transnational coordination through national and supranational bureaucracies" TARN Working Paper 2016. 3/06. https://doi.org/10.2139/ssrn.2779017. A network governance fejlődéséről lásd Jacob ToRFING Eva SøREnsEn: „The European debate on governance networks: Towards a new and viable paradigm?” Policy and Society 2014/4. 329-344. https://doi.org/10.1016/j.polsoc.2014.10.003. Lásd még az experimentalist governance témakörét: Charles F. SABEL - Jonathan Zeituin: „Learning from Difference: The New Architecture of Experimentalist Governance in the EU" European Law Journal 2008/3. 271-327. https://doi.org/10.1111/j.1468-0386.2008.00415.x. 
Fontos azonban kiemelni, hogy a jogalkotás során megkötött tagállami kompromiszszumokat az Európai Unió Bírósága (Bíróság) ítélkezése alááshatja, mivel kompetenciája az EUSZ 19. cikk (1) bekezdése szerint nemcsak az EU-jog kikényszerítése, hanem az értelmezése is, különösképpen az adott általános és speciális jogalkotási céloknak megfelelően. Az EU-jog benne rejlő sajátosságaként meghatározható az európai integráció ösztönzése a bírósági joggyakorlat által. ${ }^{15} \mathrm{Az}$ EU jogi kötelezettségek egységes és hatékony alkalmazásának nyomatékos bírósági hangsúlyozása nagymértékben korlátozta az EU belső piacán fennálló tagállami eltéréseket. ${ }^{16}$ A Bíróság joggyakorlata jelentősen kitágította a négy gazdasági szabadság alkalmazási területét, és korlátozta azon teret, amelyen belül a tagállamok megvédhetik a nemzeti érdek védelmében megszületett tagállami szabályokat és közpolitikai intézkedéseket. ${ }^{17}$

Ezekre az alapokra építve a fejezet struktúrája a következő: először a tagállami érdek koncepcióját vizsgálja a vonatkozó szakirodalom alapján, és elhelyezi a koncepciót a belső piaci jog kontextusában. A következő alfejezet röviden leírja a belső piac általános jogi keretét, fókuszálva a tagállamok rendelkezésére álló kivételek rendszerére, amelyekkel igazolhatók a kereskedelemkorlátozó intézkedések. Ez a rész azzal a közbenső konklúzióval zárul, hogy a nemzeti közérdekű kimentések jogi rendszere - főként az arányosság elve - lehetetlenné teheti a tagállamok számára legitim nemzeti közpolitikák végrehajtását. Ezen túl ez a rész érinti azt a kérdést is, hogy a Szerződésekben szereplő, nem gazdasági jellegű EU-célkitűzések mennyiben vehetők figyelembe a négy gazdasági szabadság megvalósításában (mainstreaming). A negyedik fejezet specifikus tárgya a tagállami szociálpolitikai célok érvényesülésének vizsgálata, hiszen a Bíróság jelentős kritikát kapott az egyenlő alkotmányjogi jogforrási szinten szereplő két cél (a piaci integráció és a szociális védelem biztosítása) közötti ki nem egyensúlyozott jogértelmezése miatt. Az ötödik rész a konklúziókkal zárul.

A tanulmány a terjedelmi korlátok és a belső piaci jog sokrétűsége miatt csak néhány közös, alapvető jellemzővel vet számot, a belső piaci jogon belüli egyes jogterületek vagy szabadságok feltérképezése külön tanulmányok tárgyát képezi. ${ }^{18}$

15 Mauro CAppelletti - Monica Seccombe - Joseph H. Weiler (szerk.): Integration Through Law, Europe and the American Federal Experience (Berlin: De Gruyter) 1985-1988. Bár a jogirodalom megosztott, hogy a Bíróság aktivista-e. Ezen vitát részletesen elemzi VÁRnAY Ernő: „Az Európai Bíróság és a bírói aktivizmus délibábja” Állam- és Jogtudomány 2017/2. 85-113.

${ }^{16}$ Az EU-jog tagállami szintű értelmezésének dilemmáiról lásd Somssich Réka: Egységes jog - egységes értelmezés? Az uniós jog értelmezése a tagállami bíróságok szintjén (Budapest: ELTE Eötvös Kiadó 2016).

${ }^{17}$ Lásd Hjalte Rasmussen: On law and policy in the European Court of Justice. A comparative study in judicial policymaking (Dordrecht: Martinus Nijhoff 1986); Miguel Poiares Maduro: We, the Court (Oxford: Hart Publishing 1998); Karen Alter: The European court's political power (Oxford: Oxford University Press 2009); Paul CrAIG: „Competence and Member State autonomy: casualty, consequence and legitimacy" in Hans-Wolfgang Micklitz - Bruno DE WitTe (szerk.): The ECJ and the autonomy of the Member States (Antwerp: Intersentia 2012) 11-34., Mark Dawson, Bruno DE WITTE, Elise MuIR (szerk.): Judicial activism at the European Court of Justice (Cheltenham: Edward Elgar Publishing 2013).

18 Ezekből többet feldolgozott az MTA TK-n belül müködő HPOPs-Lendület Kutatócsoport. Lásd: https://hpops.tk.mta.hw/jogi. 


\section{TAGÁLLAMI ÉRDEKEK ÉS GAZDASÁGI SZABADSÁGOK}

Amennyiben a Szerződések valamely kérdésben megosztott hatáskört ruháznak az Unióra, mind a tagállamok, mind az Unió jogilag kötelező szabályokat fogadhat el ezen hatáskör tárgyára vonatkozóan. A tagállamok azonban az EUSZ 2. cikk (2) bekezdése szerint csak annyiban gyakorolhatják a hatáskörüket, amennyiben az Unió még nem gyakorolta a sajátját. A gyakorlatban a megosztott hatáskör azt jelenti, hogy az EU elsődleges joga alkotmányjogilag elismeri a tagállamok nemzeti piacaikra vonatkozó szabályalkotási terét, mind annak piaci, mind szociális vonatkozásaira. Az elsődleges jogban ezenkívül a tagállamok szabályozási és közpolitikai autonómiájának elismerését jelentik a Szerződés által rögzített kivételek (kimentések rendszere), amelyek a tagállamokat egyedileg is felhatalmazzák arra, hogy nemzeti érdekeiknek megfelelő intézkedéseket hozzanak, természetesen a Bíróság ellenőrzése mellett és joggyakorlatának megfelelően. Ezzel ellentétben a Tanácsban a tagállamok együttesen lépnek fel a másodlagos jog megalkotása érdekében azzal a céllal, hogy a tagállami jogszabályokat egységesítsék vagy harmonizálják a belső piac céljai szerint. A jogalkotási folyamatban néhány tagállam, főként az erősebb tárgyalási pozícióban lévők, képesek lehetnek olyan kompromisszum elfogadtatására, amely föként a saját nemzeti érdekeikhez áll közel. A legáltalánosabb belső piaci jogalap, az EUMSZ 114. cikke által megkövetelt minősített többség szabálya szükségszerűen korlátozza a legtöbb tagállam azon képességét, hogy egyéni preferenciáikat érvényesítsék a jövőbeli EU jogi aktus tartalmának meghatározásában.

Elvben az EU jogi kötelezettségeknek való megfelelés olyan imperatíva, amely abból a feltételezésből fakad, hogy a tagállamok egy közös cél elérése érdekében egyesítik erőfeszítéseiket. A gyakorlatban azonban, mint ahogyan azt a politikatudományi irodalom bemutatja, a tagállamok fellépését ugyanennyire motiválja a nemzeti partikularizmus és a nemzeti érdekek egyoldalú érvényesítése. A liberális kormányköziséget valló iskola (liberal intergovernmentalism) képviselői régóta hirdetik, hogy az Unió politikai alapja az érdekek nemzeti megformálásán, majd azoknak az uniós szintủ újraformálásán alapul. Ez azon a feltételezésen alapszik, hogy „a tagállami magatartás a hazai társadalmi nyomás alatt tanúsított racionális magatartás, amelyet a külföldi stratégiai környezet is alakít." ${ }^{19}$ Ezenkívül megállapítható, hogy az EU szinten képviselt preferenciákat a kollektív fellépéssel járó költségek és előnyök is alakítják. ${ }^{20} \mathrm{~A}$ tanácsi döntéshozatalt jelentősen formálja az, hogy

19 Andrew Moravcsik: „Preferences and power in the European Community: a liberal intergovernmentalist approach" Journal of Common Market Studies 1993/4. 473-524., 474.; Andrew MoRAvcsiK: The choice for Europe. Social purpose and state power from Messina to Maastricht (Ithaca, NY: Cornell University Press 1998); lásd még Jeffry A. FRIEDEN: „Invested interests: the politics of national economic policies in a world of global finance" International Organization 1991/4. 425-451. https://doi.org/10.1017/S0020818300033178.

20 Stefanie BAILER - Mikko MatTiLA - Gerald Schneider: „Money makes the EU go round: the objective foundations of conflict in the Council of Ministers” Journal of Common Market Studies 2015/3. 437-456. https://doi.org/10.1111/jcms.12194; Paul CRAIG: „Competence and Member State autonomy: casualty, consequence and legitimacy” in Hans-Wolfgang MickLITZ - Bruno DE WITTE (szerk.): The ECJ and the autonomy of the Member States (Antwerp: Intersentia 2012) 11-34. 
milyen országszintű redisztribúciós érdekek forognak kockán, és a Tanács előtt felmerülő ellentétes ideológiai pozíciók álcája mögött is versenyző tagállami gazdasági érdekek jelennek meg. ${ }^{21} \mathrm{~A}$ döntéshozatalt dominálja a szegényebb és gazdagabb országok között húzódó strukturális hasadék is. ${ }^{22}$ Továbbá, bár a tagállami kormányok uniós mozgástere a tagállami választóktól kapott politikai mandátumból adódik, a mozgástér terjedelmére azonban döntő nyomást gyakorol az államok kölcsönös nemzetközi gazdasági, társadalmi és politikai függősége. ${ }^{23}$

Ben Clift és Cornelia Woll a gazdasági patriotizmusról szóló munkájukban felhívták arra a figyelmet, hogy a tagállamok, a területileg korlátozott politikai mandátumuk miatt mindig olyan közpolitikákat valósítanak meg, amely a nemzeti érdeket szolgálja. A hasonlóan területileg megalapozott politikai felelősségük a mandátum végrehajtására a másik indoka annak, amely miatt elsőbbséget adnak, még az európai kontextusban is, a helyi érdekek és szükségletek szolgálatának a nemzeti gazdaságpolitikájukban. Általánosságban tehát kijelenthető, hogy a tagállami kormányoknak nincs más lehetőségük, mint hogy a „nemzeti gazdasági érdek” védelmében lépnek fel. Bár a gazdasági globalizáció és regionalizáció változásokat indukál, a hazai gazdaságpolitikát a hazai gazdaság adottságai alakítják az ebben a térben behatárolt társadalmi és gazdasági megfontolásokkal. ${ }^{24}$

Jogi szempontból az EU-közpolitikák alakításában abban nyilvánul meg a leginkább a tagállami érdekek relevanciája, hogy a belső piac négy gazdasági szabadsága alóli kimentések milyen mérlegelési teret hagynak a tagállamoknak saját közpolitikáik megvalósítására.

\section{A GAZDASÁGI SZABADSÁGOK ALÓLI KIVÉTELEK ÉS A BÍRÓSÁG SZEREPE}

\subsection{A GAZDASÁGI SZABADSÁGOK TILALMI KÖRE}

A négy gazdasági szabadság történelmi funkciója a tagállami kereskedelemkorlátozások megakadályozása. Mivel a potenciális korlátozások jellege nyitott, és a belső piac meghatározása túlságosan tág, a Szerződés vonatkozó rendelkezései az integrációs folyamat kezdetétől értelmezésre szorultak. Az Európai Bíróság jogértelmezésének eredményeképpen mostanra a belső piaci szabadságok alkalmazási körének kiterjesztése és az ennek következtében fellépő gyakorlati hatások többszörösen

${ }^{21}$ Bailer-Mattila-Schneider (20. lj.) 451-452.

22 Bailer-MatTila-Schneider (20. lj.), 451-453.

${ }^{23}$ Lásd ebben az értelemben Colin Crouch: Making capitalism fit for society (Cambridge, MA: Polity Press 2013); Jukka SNELL: „The trilemma of European economic and monetary integration, and its consequences" European Law Journal 2016/2. 157-179. https://doi.org/10.111//eulj.12165 (a monetáris unió kontextusában).

${ }^{24}$ Ben CliFT - Cornelia Woll: „Economic patriotism: reinventing control over open markets” Journal of European Public Policy 2012/3. 307-323, 311-312. https://doi.org/10.1080/13501763.2011.63 8117. 
meghaladták a korábban működési területként elképzelt kereteket. ${ }^{25}$ A gazdasági szabadságok a piacra jutás biztosításán túl is túlterjeszkednek, az árukhoz és szolgáltatásokhoz való hozzájutás szabadságát, valamint a vállalkozások exportját és a tőke kiáramlását is garantálják. ${ }^{26}$ A tagállami kötelezettségek ilyen mértékủ kiterjesztésének természetes hatása volt azok közpolitikáira és szabályozási autonómiájára. A gazdasági szabadságok kiterjesztett alkalmazási köre megnövelte a tagállami jogsértések elkövetésének esélyét is. Mivel „tulajdonképpen minden tagállami közpolitikai választást fel lehet fogni a szabad mozgás potenciális korlátjaként”, ${ }^{27}$ ezért a jogi vizsgálat hangsúlya eltolódott afelé, hogy a tagállamok milyen módon menthetik ki a tagállami érdek védelmében született intézkedéseiket. ${ }^{28}$

A Szerződés hatálya alá eső korlátozások köre fokozatosan tágult ki. Általában hat különböző fejlődési irányt lehet elkülöníteni. Először is, az Európai Bíróság folyamatosan korlátozta azon helyzeteket (tisztán hazai szituációk), amelyekre a Szerződést nem kell alkalmazni, és így kiterjesztette a belső piaci szabadságok alkalmazási körét. ${ }^{29}$ Másodrészt, a joggyakorlat hagyományosan szélesen értelmezi a gazdasági tevékenység fogalmát, és ezzel a gazdasági jog benyomul a tagállamok szociális és általában redisztribúciós autonómiájába. Harmadrészt, a Bíróság kategorikusan elutasította, hogy vannak olyan területek, amelyek a tagállamoknak fenntartott vagy a belső piaci jog alkalmazása alól kivett hatáskörök. ${ }^{30}$ Negyedszer, a belső piaci szabadságok mostanra már nemcsak a tagállami intézkedésekre alkalmazhatók, hanem a személyi hatály kiterjesztésével több horizontális jogviszonyban is. ${ }^{31}$ A Laval-és Viking-

${ }^{25}$ Diamond Ashiagbor: „Unravelling the embedded liberal bargain: labour and social welfare in the context of EU market integration” European Law Journal 2013/3. 303-324. https://doi.org/10.111/ eulj.12025; Nobert REICH: „How proportionate is the proportionality principle? Some critical remarks on the use and methodology of the proportionality principle in the internal market case law of the ECJ" in Hans-Wolfgang Micklitz - Bruno DE WiTTE (szerk.): The European Court of Justice and the autonomy of the Member States (Antwerp: Intersentia 2012) 83-111.

${ }^{26}$ Norbert REICH: „How proportionate is the proportionality principle? Some critical remarks on the use and methodology of the proportionality principle in the internal market case law of the ECJ" in Hans-Wolfgang Micklitz - Bruno DE WiTTE (szerk.): The European Court of Justice and the autonomy of the Member States (Antwerp: Intersentia 2012) 83-111.

27 Niamh Nic Shuibhne: „Primary laws: judging free movement restrictions after Lisbon” in Panos Koutrakos - Niamh Nic Shuibhne - Phil Syrpis (szerk.): Exceptions from EU free movement law. Derogation, justification and proportionality (Oxford: Hart Publishing 2016) 297-318., 299.

28 A magyar irodalomban Józon Mónika is rávilágított, hogy például a fogyasztóvédelmi célú tagállami mozgástér nagyon szűkös. Lásd Józon Mónika: „Az áruk szabad mozgása az Európai Unióban, és a tagállami fogyasztóvédelem érvényesülése a negativ és pozitív integráció közötti összefüggések tükrében" Jogtudományi Közlöny 2019/6. 251-265.

${ }^{29}$ Az újabb bírói gyakorlatból lásd a C-268/15. sz. Fernand Ullens de Schooten ügyben 2016. november 15-én hozott ítéletet, EU:C:2016:874. Peter Oliver- Wulf-Henning Roтн: „The internal market and the four freedoms" Common Market Law Review 2004/2. 407-431, 431.; Cyril RITTER: „Purely internal situations, reverse discrimination, Guimont, Dzodzi and Article 234.” European Law Review 2006. 690-710., 706., Sara Iglesias SÁnchez: „Purely internal situations and the limits of EU law: A consolidated case law or a notion to be abandoned? European Constitutional Law Review 2018/1. 7-36. https://doi.org/10.1017/S1574019618000111.

${ }^{30}$ Lásd például a C-106/77. sz. Amministrazione delle Finanze dello Stato kontra Simmenthal SpA ügyben 1978. március 9-én hozott ítéletet, EU:C:1978:49.

31 C-36/74. sz. Walrave és Koch ügyben 1974. december 12-én hozott ítélet, EU:C:1974:140, 18. pont és C-171/11. sz. Fra.bo SpA ügyben 2012. július 12-én hozott ítélet, EU:C:2012:453. A személyi hatály 
ítéletekben a Bíróság a szakszervezetek szociális fellépését minősítette belső piaci korlátozásnak. ${ }^{32}$ Ötödször, az import korlátozásán kívül minden exportkorlátozást is jogsértőnek tart a Bíróság, amely például a vállalkozás szabadságának körében súlyos következményekkel járhat a letelepedés államának szabályozását tekintve. Hatodszor és legfontosabbként, a Bíróság a korlátozás mértékének küszöbét nagyon alacsonyan határozta meg. A joggyakorlat sohasem fogadta el de minimis mérce vagy más kvantitatív szabály alkalmazásának lehetőségét, és úgy ítélkezett, hogy a tagállami korlátozások tiltottak, azok csekély tárgyi hatálya vagy kisebb jelentőségük és alacsony szintű kereskedelemkorlátozó hatásuk ellenére. ${ }^{33} \mathrm{Az}$ egyetlen hasonló funkciójú teszt a korlátozások körét azon az alapon szükíti, hogy a kereskedelemkorlátozás és a tagállami intézkedés közötti kapcsolat túlságosan bizonytalan vagy közvetett, amely viszont a kettő közötti okozati összefüggésre vonatkozik. ${ }^{34}$ A fentiek szerint az EU jog megsértése megállapítható olyan esetekben, amelyekben a korlátozásnak csak marginális vagy közvetett potenciális hatása van, azon esetek kivételével, amelyekben a korlátozás csak hipotetikus jellegü. ${ }^{35}$ Ennek eredményeként a következetes bírói joggyakorlat a korlátozás fogalmát úgy határozza meg mint (1) minden olyan intézkedés, amely alkalmas arra, hogy korlátozza vagy kevésbé vonzóvá tegye a szabadság gyakorlását, vagy (2) alkalmas arra, hogy megtiltsa, korlátozza vagy nehezebbé tegye/kevésbé vonzóvá tegye a szabadság gyakorlását, vagy (3) valószínüleg elrettentő hatású. ${ }^{36}$

kiterjesztésének több módszere van. Az első a horizontális hatály, amikor magánszemély is köteles a szabadság biztosítására például a munkavállalók szabad áramlása területén. C-281/98 Angonese kontra Cassa di Risparmio di Bolzano ügyben 2000. június 6-án hozott ítélet. (EU:C:2000:296) A második kiterjesztési mód a kollektív szabályozási hatást eredményező magánszemélyek köre, amely a tőkeáramlás kivételével mindegyik szabadságot jellemzi. Erre a legtipikusabb a sportszervezetek köre. A harmadik kiterjesztési módszerre az áruáramlás a legjobb példa, mikor a magánszemélyek korlátozásaiért az állam felel. Az angol irodalomból ezt a joggyakorlatot feldolgozza: Niamh Nic Shuibhne: The Coherence of EU Free Movement Law. Constitutional Responsibility and the Court of Justice (Oxford: Oxford University Press 2013) 100-108. https://doi.org/10.1093/ acprof:oso/9780199592951.001.0001. A magyar irodalomból lásd PAPP Mónika: Gazdasági szabadságok és a közös piaci versenyjog egyes összefüggései az Európai Bíróság joggyakorlatában. (PhD-dolgozat, kézirat, 2006) 91-122. https://www.ajk.elte.hw/file/AJKDI_PappMonika_dis.pdf.

32 C-438/05. sz. International Transport Workers' Federation and Finnish Seamen's Union kontra Viking Line ABP and oÜ Viking Line Eesti ügyben 2009. december 11-én hozott ítélet, EU:C:2007:772 és C-341/05. sz. Laval un Partneri Ltd. kontra Svenska Byggnadsarbetareförbundet ügyben 2007. december 18-án hozott ítélet, EU:C:2007:809.

33 A de minimis hatás elutasításától lásd a C-16/84.sz. Commission kontra Netherlands ügyben 1985. július 10-én hozott ítéletet, EU:C:1985:309, a 177 és 178/82. sz. Criminal procedings against Jan van de Haar and Kaveka de Meen BV egyesített ügyekben 1984. április 4-én hozott ítéletet, EU:C:1984:144, és a C-126/91.sz. Schutzverband gegen Unwesen in der Wirtschaft e.Vv kontra Yves Rocher GmbH ügyben 1993. május 18-án hozott ítéletet, EU:C:1993:191.

${ }^{34}$ C-69/88. sz. Krantz ügyben 1990. március 7-én hozott ítélet, EU:C:1990:97, C-190/98. sz. Volker Graf kontra Filzmoser Maschinenbau GmbH ügyben 2000. január 27-én hozott ítélet, EU:C:2000:49.

${ }^{35}$ C-16/83. sz. Criminal proceedings against Karl Prantl ügyben 1984. március 13-án hozott ítélet, EU:C:1984:101, C-177.sz. és 178/82. sz. Criminal proceedings against Jan van de Haar and Kaveka de Meern BV egyesített ügyekben 1984. április 5-én hozott ítélet, C:1984:144.

${ }^{36} \mathrm{Az}$ áruk és szolgáltatások szabadságának esetében a joggyakorlat a piacra jutási tesztet alkalmazza. Lásd a C-267/91.sz. és C-268/91.sz. Criminal proceedings against Bernard Keck and Daniel Mithouard egyesített ügyekben 1993. november 24-én hozott ítélet, EU:C:1993:905, C-108/09.sz. Ker-Optika Bt. ügyben 2010. december 2-án hozott ítélet, EU:C:2010:725. 
A joggyakorlat jelentős számú ütközést eredményezett a tagállamok legitim nemzeti közpolitikai intézkedései és az EU belső piaci joga között. Megnövekedett azon konfliktusok száma, amelyek egy valódi közös belső piac megteremtésének és fenntartásának célja, valamint másik oldalról egyes tagállamok helyi közpolitikai jellegzetességének és ezek fokozottabb megőrzésének célja között húzódnak. Ez a megállapítás különösen igaz azon közpolitikákra, mint a szociális politika, a kultúra és a közoktatás, amelyekben az EU-nak csak korlátozott hatásköre van, de a gazdasági szabadságok hatálya alá tartoznak, és ezért a belső piac hatása ezen hatáskörök gyakorlása során is érzékelhető. Mivel a gazdasági szabadságoknak azokon a területeken is érvényesülniük kell, amelyeken a tagállamok saját tagállami szintű hatásköreiket gyakorolják, ezért Gareth Davies szerint nehéz az életnek egy olyan területét megnevezni, ahová a belső piac nem türemkedik be azon követeléssel, hogy a belső piacból fakadó egyéni jogokat érvényesíteni kell. ${ }^{37} \mathrm{~A}$ politikai mandátumuk teljesítésének célját követő tagállami kormányok elégedetlenségének másik forrása az, hogy az Európai Bíróság kiterjesztő joggyakorlatából adódó negatív integrációt és helyi deregulációs hatást gyakran nem kompenzálja az európai jogharmonizációs folyamat pozitív integrációs hatása. Mint Weatherill megjegyezte:

„A belső piaci kereskedelem felszabadításának túlságosan hangsúlyos ösztönzése az egyéni tagállami szabályozási érzékenység rovására azzal a veszéllyel jár, hogy a jogi deregularizáció túlságosan mély lesz - annál is mélyebb, ahogyan az a Szerződésből következik.” A piaci deregularizáció ugyanezen túlhangsúlyozása azzal a kockázattal is jár, hogy a belső piac megalkotását túlságosan ráterheljük a bírósági eszközökre - a szabad áramlás jogára - az EU-jogalkotás - föként harmonizáción keresztüli - kiegészítő szerepének rovására. Weatherill megállapítását főként a kölcsönös elismerés elvére alapozta. ${ }^{38}$

\subsection{TAGÁLLAMI KIMENTÉSI LEHETÖSÉGEK}

Ahogyan a Szerződés rendelkezik erről, amennyiben egy nemzeti intézkedés alkalmas a tagállamok közötti kereskedelem befolyásolására, a tagállami szabályozási kompetencia gyakorlásának az a feltétele, hogy a tagállam bizonyítsa: egy releváns közpolitikai cél elérése érdekében szükséges és arányos az intézkedés. Ennek a kimentésnek a tétjét jól érzékelteti Barnard, aki szerint „az alperes tagállam számára minden sikertelen kimentés egy szög a jogalkotási autonómiájának koporsójába és általánosabban, a nemzeti szabályok közötti különbségek számára." ${ }^{39}$ Egy másik

${ }^{37}$ Gareth Davies: „Internal market adjudication and quality of life in Europe” Columbia Journal of European Law 2015/2. 289-328.

${ }^{38}$ Stephen WeatheriLL: „Why there is no "principle of mutual recognition" in EU law (and why that matters to consumer lawyers)" in Kai PURnhAGEN - Peter RotT (szerk.): Varieties of European economic law and regulation (Berlin: Springer Publishing 2014) 401-418, 401. https://doi. org/10.1007/978-3-319-04903-8_19.

${ }^{39}$ Catherine BARNARD: „Derogations, justifications and the four freedoms: is state interest really protected?" in Catherine BARNARD - Okeoghene ODUDU (szerk.): The outer limits of European Union law (Oxford: Hart Publishing 2009) 273-306., 274. 
megfogalmazásban ugyanő azt vetette fel, hogy „a Cassis de Dijon adok és kapok világában, a kimentések az adok kategóriájába tartozik, ez a cukormáz a tagállamok számára, amelyet a tagállamok a piaci integráció adott esetben keserủ pirulájával együtt nyelnek le." 40

Első ránézésre úgy tűnik, hogy a jog rengeteg választást kínál a tagállamok számára az EU által legitimnek tekintett közérdekű céljaik megvalósítására. ${ }^{41}$ A Szerződés szövege is köztudottan számos kivételre kínál lehetőséget a legfontosabb tagállami érdekek megóvása érdekében, úgy, mint a közrend védelme, közbiztonság, közegészségügy és közerkölcsök védelme. A bírói joggyakorlat ezt a listát jelentősen tovább szélesítette a nem diszkriminatív tagállami közpolitikai intézkedések kimenthetőségét tekintve olyan további közérdekekkel, mint a fogyasztóvédelem, környezetvédelem, munkavállalók védelme, hitelezők védelme, szakmai etika védelme, kollektív fellépés biztosítása érdekében, a nemzeti adórendszer koherenciájának védelme vagy például az adócsalás megelőzése és az elleni fellépés védelme. (Ezeket a követelményeket az áruk szabad áramlása területén kényszerítő vagy feltétlenül érvényesítendő követelményeknek, más szabadságok esetén közérdeken alapuló nyomós indoknak is nevezzük.) A tagállami intézkedések elfogadhatósága azonban nagyobbrészt attól függ, hogy a szükségesség-arányosság tesztjét kiállják-e, úgy ahogyan azt az Európai Bíróság alkalmazza az egyes ügyek egyéni értékelésekor.

A tagállamoknak nincs teljes mérlegelési szabadságuk a kimentéskor annak meghatározására, hogy mi tekinthető közérdekủ célnak. Az Európai Bíróság még az olyan tágan meghatározott kimentési okok esetében is, mint a közrend és közbiztonság, megszorító értelmezést alkalmaz, és saját kontrollját kiterjeszti a tagállamok által egyoldalúan meghatározott fogalmakra. ${ }^{42}$ A tagállamok kizárólag akkor hivatkozhatnak sikerrel a közrend védendő érdekére, amennyiben a társadalom valamely alapvető érdekét valódi és kellően súlyos fenyegetés éri. ${ }^{43}$ A kivételekre való hivatkozást az is szükítheti, ha az adott jogi tárgyat másodlagos EU jogi norma szabályozza, mivel a tagállamok nem veszélyeztethetik egyoldalú intézkedéseikkel az EU másodlagos jogi normák céljainak elérését. Ennek ellenkezője is igaz: ha a tagállami közpolitikai célkitűzések és az EU szabályozás célkitűzései kiegészitik egymást, a Bíróság kész a kettő közötti szinergiák fenntartására, és a tagállam által hivatkozott közérdekủ célt védelemben részesíteni. ${ }^{44}$

${ }^{40}$ BaRnard (39. lj.), 273.; lásd még Stephen Weatherill: The internal market as a legal concept. (Oxford: Oxford University Press 2017) 99. https://doi.org/10.1093/acprof:oso/9780198794806. 001.0001 .

${ }^{41}$ Jürgen Schwarze: „Balancing EU integration and national interests in the case-law of the Court of Justice" in Allan RosAs - Egils Levits - Yves Bot (szerk.): The Court of Justice and the construction of Europe: analyses and perspectives on sixty years of case-law (The Hague: T. M. C. Asser Press 2013) 257-278. https://doi.org/10.1007/978-90-6704-897-2_15.

${ }^{42}$ C-41/74. sz. van Duyn ügyben 1974. december 4-én hozott ítélet, EU:C:1974:133.

${ }^{43}$ C-41/74. sz. van Duyn ügyben 1974. december 4-én hozott itélet, EU:C:1974:133.

${ }^{44}$ Lásd többek között C-452/01.sz. Margarethe Ospelt and Schlössle Weissenberg Familienstiftung ügyben 2003. szeptember 23-án hozott ítéletet, EU:C:2003:493, 40. pont és C-10/10.sz. Commission kontra Austria ügyben 2011. június 16-án hozott ítéletet, EU:C:2011:399, 32, 34. és 37. pontok, és a C-105/12.sz. ügytöl a C-107/12. sz. ügyig terjedő az Essent ügyben 2013. október 22-én hozott itéleteket az egyesített ügyekben, EU:C:2013:242, 58-65. pontok. 
Bár az Európai Bíróság általában nyitott számos tagállami közpolitikai cél legitimként való elfogadására, következetesen visszautasította gazdasági jellegű (tisztán gazdasági) érdekek elfogadását vagy azokat a hivatkozásokat, amelyekben a tagállamok közigazgatási nehézségekre hivatkoztak. Így nem fogadta el az adóbevételek csökkenésének érvét, a szabályozott vállalkozások profitjának csökkenését, az EU-tagsággal járó általános költségvetési és pénzügyi következményeket, adott szektorok vagy vállalkozások versenyképességének növelését. Mindezek önmagukban nem szolgálhatnak kereskedelemkorlátozások igazolására. ${ }^{45,46}$ Gazdasági jellegű érdekek kizárólag annyiban fogadhatók el, amennyiben kapcsolódnak a tagállami közpolitika más, nem gazdasági jellegủ érdekeinek védelméhez. Ez főként az egészségügyi szektort szabályozó tagállami intézkedésekkel kapcsolatban figyelhető meg. ${ }^{47}$ Bár a Bíróság elutasítja a tagállami bevételek növelésének célját jogszerủ kimentési okként, mégis elfogadhatónak tartotta, hogy a tagállami korlátozások járulékos következményként a költségvetésre pozitívan hatnak, és igazolhatóságuk más közérdekün alapuló kényszerítő indok alapján fennáll. ${ }^{48}$

A Bíróság szélesebb mérlegelési teret hagyott a tagállamoknak olyan társadalmi koncepciók értelmezésében, amelyek eltérő erkölcsi vagy kulturális felfogásuk miatt tagállamonként különbözők. ${ }^{49}$ Hasonlóan ehhez a Bíróság az érdekek közötti egyensúlyozás terén óvatosságot mutatott, amennyiben a versenyző tagállami érdek a közegészség védelme volt, és a tagállamok számára biztosította annak lehetőségét, hogy az emberek életének és egészségének védelme érdekében hozzanak intéz-

${ }^{45}$ Sue ARRowsmith: „Rethinking the approach to economic justifications under the EU's free movement rules" Current Legal Problems 2015/68. 307-365. https://doi.org/10.1093/clp/cuv011; Peter Oliver: „When, if ever, can restrictions on free movement be justified on economic grounds?” European Law Review 2016/2. 147-175.

${ }^{46}$ Lásd többek között a C-367/98. sz. Bizottság kontra Portugália ügyben 2002. június 4-én hozott ítéletet, EU:C:2002:326, 52. pont.

${ }^{47}$ Lásd többek között az C-120/95. sz. Nicolas Decker and Caisse de Maladie des Employés Privés ügyben 1998. április 28-án hozott ítéletet, EU:C:1998:167, 39. pont, amelyben a Bíróság elfogadta a társadalombiztosítási rendszer pénzügyi egyensúlyában okozott súlyos kár fennállásának veszélyét mint közérdeket és C-158/96. sz. Raymond Kohll kontra Union des caisses de maladie ügyben 1998. április 28-án hozott itélet, EU:C:1998:171.

${ }^{48}$ Ilyen esetekben az intézkedése elsődleges indoka a tagállami erkölcsi, vallási vagy kulturális rend sajátosságainak védelme, valamint a szerencsejátékoknak és fogadásoknak a társadalomra és az egyénre nézve erkölcsi, illetve anyagi szempontból egyaránt káros következményei. C-67/98.sz. Questore di Verona kontra Diego Zenatti ügyben 1999. október 21-én hozott ítélet, EU:C:1999:514; C-243/01. sz. Criminal proceedings against Piergiorgio Gambelli and Others ügyben 2003. november 6-án hozott ítélet, EU:C:2003:597. Ezt Jan ZGLINSKI közpolitikai deferenciának nevezi, ugyanis a tagállami jogalkotó/közigazgatás határozza meg a védett közcélt, azaz a Bíróság nem avatkozik be. Zglinski idesorolja az Omega, Schindler, Van Duyn, Henn and Darby ítéleteket. 41/74. sz. Van Duyn kontra Home Office ügyben 1974. december 4-én hozott ítélet, EU:C:1974:133; 34/79. sz Henn and Darby ügyben 1979. december 14-én hozott itélet, EU:C:1979:295; C-275/92. sz. H. M. Customs and Excise kontra Schindler ügyben 1994. március 24-én hozott ítélet, EU:C:1994:119; C-36/02.sz. Omega Spielhallen- und Automatenaufstellungs-GmbH kontra Oberbürgermeisterin der Bundesstadt Bonn ügyben 2004. október 14-én hozott ítélet, EU:C:2004:614.

${ }^{49}$ C-244/06. sz. Dynamic Medien Vertriebs GmbH kontra Avides Media AG ügyben 2008. február 14-én hozott ítélet, EU:C:2008:85. Lásd még a C-36/02. sz. Omega Spielhallen- und Automatenaufstellungs-GmbH kontra Oberbürgermeisterin der Bundesstadt Bonn ügyben 2004. október 14-én hozott ítéletet, EU:C:2004:614. 
kedéseket. ${ }^{50}$ Diffúz közpolitikai területeken a Bíróság elfogadta, hogy a tagállamok szociális politikai döntését költségvetési megfontolások is motiválják más legitim közpolitikai célokkal párhuzamosan. ${ }^{51}$

A Bírósági joggyakorlat nem teljesen egyértelmủ és konzisztens a tekintetben, hogy egy érdek gazdasági érdek-e. A klasszifikáció így jelentős vitákat generál, hiszen a Bíróság elutasítja a tisztán gazdasági érdekek érvényesítésének lehetőségét. Ahogyan Snell rávilágított, „az a döntés, hogy egy érdek pusztán gazdasági érdek, a politika világából a piac világába helyezi át az adott ügyet."52 Ugyanő jegyezte meg, hogy a gazdasági és nem gazdasági érdek közötti határvonal meghúzása valószínủleg egyre nehezebb feladat lesz. ${ }^{53}$ Snell három stratégiát (elkerülés, elutasítás és összekapcsolás) különböztetett meg, amellyel a Bíróság megközelítette, vagy inkább elkerülte ezen problémás és zavart keltő szétválasztást. ${ }^{54} \mathrm{Az}$ első stratégia szerint a Bíróság elkerüli a szétválasztás problémáját, és anélkül dönti el az ügyet. A másik stratégia az elutasítás, amikor a Bíróság nem fogadja el azt a tagállami érvelést, hogy az érdek nem gazdasági jellegü. A harmadik stratégia alapján, amely a tagállamoknak a legkedvezőbb, a Bíróság összekapcsolja a gazdasági és nem közpolitikai gazdasági érdekeket, és így teszi azokat elfogadhatóvá. ${ }^{55}$

A felhívott közérdek elvi elfogadása nem azt jelenti, hogy a tagállam mentesül azon bizonyítási kötelezettsége alól, hogy a vitatott intézkedés ténylegesen a közérdeket szolgálja. A bizonyítékok összegyüjtése és prezentálása komoly nehézségeket okozhat az érintett tagállamoknak. A bizonyítás szintje nem teljesen világos, és valószínűleg az sem egyértelmű, hogy pontosan mit kell bizonyítani. Felmerült a jogirodalomban, hogy az alkalmazott bizonyítási standardra vonatkozóan nincs részletes információ a belső piaci esetjogban, bár szükség lenne a Bíróság jogfejlesztő tevékenységére. ${ }^{56}$

Mint már említettük, a tagállamok nem határozhatják meg egyoldalúan az igazolás terjedelmét. ${ }^{57}$ A Bíróság ellenőrzése arra irányul, hogy a tagállamok ne manipulál-

${ }^{50}$ C-170/04. sz. Rosengren ügyben 2007. június 5-én hozott ítélet, EU:C:2007:31, 39. pont.

51 C-22/13. sz. Raffaella Mascolo and Others kontra Ministero dell'Istruzione, dell'Università e della Ricerca and Comune di Napoli ügyben 2014. november 26-án hozott ítélet, EU:C:2014:2401.

52 Jukka SNell: „Economic justifications and the role of the state” in Panos Koutrakos - Niamh Nic Shuibhne - Phil Syrpis (szerk.): Exceptions from EU free movement law. Derogation, justification and proportionality (Oxford: Hart Publishing 2016) 12-31., 14.

${ }^{53}$ Lásd SNell (52. lj.) 13.

54 Lásd SNell (52. lj.) 14.

${ }_{55}$ C-137/09. sz. Marc Michel Josemans kontra Burgemeester van Maastricht ügyben 2010. december 16-án hozott ítélet, EU:C:2010:774, 18-19. pontok; C-385/99.sz. V. G. Müller-Fauré kontra Onderlinge Waarborgmaatschappij OZ Zorgverzekeringen UA and E. E. M. van Riet kontra Onderlinge Waarborgmaatschappij ZAO Zorgverzekeringen ügyben 2003. május 13-án hozott ítélet, EU:C:2003:270.

${ }^{56}$ Niamh Nic Shuibhne - Marsela Maci: „Proving public interest: the growing impact of evidence in free movement case law" Common Market Law Review 2013/4. 965-1006., 966.

${ }^{57}$ C-54/99. sz. Association Eglise de scientologie de Paris and Scientology International Reserves Trust kontra The Prime Minister ügyben 2000. március 14-én hozott ítélet, EU:C:2000:124, 17. és 48. pontok; C-483/99. sz. Commission kontra France ügyben 2002. június 4-én hozott ítélet, EU:C:2002:327; C-503/99. sz. Commission kontra Belgium ügyben 2002. június 4-én hozott ítélet, EU:C:2002:328, 72. pont; C-463/00. sz. Commission kontra Spain ügyben 2003. május 13-án hozott 
hassák (visszaélés-szerűen) a közérdekű kimentéseket; a kérdéses tagállami intézkedésnek a felhívott közérdekủ célt kell szolgálnia, az intézkedés logikája nem lehet ellentmondásos, és legföképpen a gazdasági szabadságok nem foszthatók meg minden gyakorlati hatásuktól. Ezen utolsó feltétel kizárja a túlságosan korlátozó nemzeti intézkedéseket és az olyan intézkedéseket, amelyek szükségtelenek a kívánt cél eléréséhez. A tagállami intézkedés céljának megállapítása nehézségeket is rejthet magában. Amennyiben a szövege, főként a preambuluma vagy a jogszabály előkészítő iratok nem határozzák meg a szabályozás célját, akkor az Európai Bíróság azzal a problémával találja magát szemben, hogy neki kell meghatároznia azt a tagállami közpolitikai aktorok helyett. ${ }^{58}$ Hasonlóan nehéz az Európai Bíróság számára komplex közpolitikák esetén annak meghatározása, hogy több közérdekủ cél hogyan viszonyul egymáshoz, milyen hierarchia áll fenn közöttük. ${ }^{59}$ Ezt megoldandó a Bíróság az adott kormány érvelésére támaszkodhat (azaz elfogadja a tagállam álláspontját), a közérdekủ cél meghatározását tekintheti olyan ténykérdésnek, amelynek meghatározása az előzetes döntést kezdeményező tagállami bíróság feladata (azaz elfogadja ebben a kérdésben a tagállami bíróság megállapítását), vagy a Bíróság fent is tarthatja magának a jogot a végső döntés meghozatalára. Az első esetben a tagállam hajlamos lehet a közérdek olyan módon való meghatározására, hogy az az EU jogi keretben elfogadható legyen, amely viszont valószínüleg szükségessé teszi, hogy az Európai Bíróság ne vonuljon ki a meghatározás felülvizsgálatának területéről. A másodikként felvázolt esetben a Bíróság megközelítése annak veszélyét is megteremtheti, hogy a nemzeti bíróság előtt folyamatban lévő eljárás átpolitizálódik. A harmadik szcenárió kockázata, hogy az Európai Bíróság lép a tagállami közpolitikai szereplők helyébe. A joggyakorlat mindegyik helyzetre és kombinációjukra is számos példát nyújt. Például a Bíróság arra a következtetésre jut, hogy a közérdekủ célt az intézkedés nem védi konzisztens módon, vagy a Bíróság dönt ugyan a közérdekű cél elvi elfogadásáról, de a tagállami bíróságra hárítja, hogy az intézkedés ténylegesen célját meghatározza. A gyakorlatban tehát a Bíróság hozzáállása esetről esetre alakul a körülményektől függően és attól is függően, hogy a nemzeti bíróságok hogyan tálalják a tényeket az Európai Bíróságnak. ${ }^{60}$ A Bíróság De Sousa szerint „nyomás alatt van, hogy nagyon érzékeny kérdéseket a látszólag politikailag semleges jogi érvelés leple alatt tárgyaljon”. ${ }^{61}$

Amennyiben a tagállami intézkedés céljait bizonyították, a következő lépcső a szükségességi és arányossági teszt átugrása. Ez egy komoly jogi akadályt jelent,

itélet, EU:C:2003:272; C-106/77. sz. Amministrazione delle Finanze dello Stato kontra Simmenthal SpA ügyben 1978. március 9-én hozott ítélet, EU:C:1978:49.

58 Természetesen az Európai Bíróság előtt folyamatban lévő ügyekben a tagállami bíróságok, illetve az észrevételt tevő tagállami kormányok hivatkoznak a védendő tagállami közérdekre.

${ }^{59}$ C-333/14. sz. Scotch Whisky Association and Others kontra The Lord Advocate and The Advocate General for Scotland ügyben 2015. december 23-án hozott ítélet, EU:C:2015:845, 45. pont.

${ }^{60}$ Lásd erről Urška ŠADL - Anna WALLERMANN: „'The referring court asks, in essence': Is reformulation of preliminary questions by the Court of Justice a decision writing fixture or a decision-making approach?" European Law Journal 2019/4. 416-433. https://doi.org/10.1111/eulj.12335.

61 Pedro Caro De Sousa: The European fundamental freedoms. A contextual approach. (Oxford: Oxford University Press 2015) 226. https://doi.org/10.1093/acprof:oso/9780198727729.001.0001. 
és az Európai Bíróság jogi tesztje a tagállami kormányok által előterjesztett számos érdek gyakorlati megvalósítását kizárja. Főként azért, mert először is meg kell állapítani, hogy alkalmas a felhívott cél elérésére (kapcsolat a célok és eredmények között), majd nem léphet túl a cél eléréséhez szükséges mértéken. ${ }^{62}$ Korlátozott mértékben a Bíróság elvégzi a szük értelemben vett arányossági tesztet, amelynek során a szóban forgó különböző érdekek között egyensúlyoz. ${ }^{63}$ Ezen teszt során a tagállamnak kell részletesen kifejtenie és bizonyítania, hogy például az intézkedés megfelelően célzott-e a releváns közérdekű cél elérésére, és vannak-e más olyan, kevésbé korlátozó alternatív intézkedések, amelyekkel ugyanazt a célt hasonló hatékonysággal lehet elérni. Azok az intézkedések az előnyösebbek, amelyek nem tartalmaznak abszolút tilalmakat, ex ante ellenőrzéseket, nem zárják ki a gazdasági szereplők autonómiáját aránytalanul, vagy piaci mechanizmusokhoz folyamodnak. Ezen túl a tagállami korlátozásoknak meg kell felelniük az EU alapjogainak és jogállamisági követelményeinek. ${ }^{64}$

Amennyiben a korlátozás jogi formáját tekintve nem szabályozási eredetủ, hanem tagállami közigazgatási gyakorlat, az EU-jog elöírja, hogy a közigazgatási mérlegelési jogkört következetesen és szisztematikusan kell gyakorolni, ${ }^{65}$ a tagállami hatóságok rendelkezésére álló mérlegelési jogkört korlátozni szükséges különösen a jogállamiság és a megfelelő ügyintézés elvéből eredő követelmények betartásával. ${ }^{66}$ A jogállamiság elvéből következik a tagállami közigazgatási mérlegelési jogkör korlátozásának objektív, hátrányos megkülönböztetéstől mentes és előzetesen ismert kritériumokon kell alapulnia, amelyek kellőképpen korlátok közé szorítják a nemzeti hatóságok mérlegelési jogkörének gyakorlását annak érdekében, hogy azt ne tehessék önkényes módon. ${ }^{67}$ Bármilyen eljárásjogi szabálynak, amely a közigazgatási engedélyek megadására vonatkozik, könnyen hozzáférhetőnek kell lennie, és a határozatokat észszerű határidőn belül kell meghozni. A közigazgatási határozatokat megfelelően indokolni kell, azoknak az adott közérdekű cél eléréséhez következetesen és szisztematikus módon kell hozzájárulniuk, a határozatokkal szemben hatékony bírói jogorvoslatot kell biztosítani. ${ }^{68}$

62 Jan H. JANS: „Proportionality revisited” Legal Issues of Economic Integration 2000/3. 239-265.

${ }^{63}$ Lásd például C-44/79.sz. Liselotte Hauer kontra Land Rheinland-Pfalz ügyben 1979. december 13-án hozott ítélet, EU:C:1979:290.

${ }^{64}$ C-260/89. sz. ERT ügyben 1991. június 18-án hozott ítélet, EU:C:1991:254; C-112/00. sz. Eugen Schmidberger, Internationale Transporte und Planzüge kontra Republik Österreich ügyben 2003. június 12-én hozott ítélet, EU:C:2003:333; C-36/02. sz. Omega Spielhallen- und Automatenaufstellungs-GmbH kontra Oberbürgermeisterin der Bundesstadt Bonn ügyben 2004. október 14-én hozott ítélet, EU:C:2004:614.

${ }^{65}$ C-243/01.sz. Criminal proceedings against Piergiorgio Gambelli and others ügyben 2003. november 6-án hozott ítélet, EU:C:2003:597

${ }^{66}$ Gjermund Mathisen: „Consistency and coherence as conditions for justification of Member State measures restricting free movement" Common Market Law Review 2010/4. 1021-1048, 2010.

${ }^{67}$ Lásd például a C-326/07. sz. Commission kontra Italy ügyben 2009. március 26-án hozott ítéletet, EU:C:2009:193; C-367/98. sz. Commission kontra Portugal ügyben 2002. június 4-én hozott ítélet, EU:C:2002:326; C-302/97. sz. Klaus Konle kontra Republik Österreich ügyben 1999. június 1-jén hozott ítélet EU:C:1999:271.

${ }^{68}$ C-205/99. sz. Analir ügyben 2001. február 20-án hozott ítélet, EU:C:2001:107; C-3/17. sz. Sporting Odds Limited kontra Nemzeti Adó- és Vámhivatal Központi Irányítása ügyben 2018. február 28-án 
A tagállamok ezzel kapcsolatos bizonyítási kötelezettsége elég jelentős is lehet. A tagállami kormányoknak kell pontos és következetes bizonyítékokat előterjeszteni az intézkedés szükségességéről és arányosságáról, bár ez a bizonyítási teher nem terjedhet annak pozitív bizonyításáig, hogy semmilyen más elképzelhető alternatív intézkedés nem alkalmas az adott közérdekű cél ugyanolyan feltételekkel történő biztosítására. ${ }^{69}$ Shuibhne és Maci szerint a Bíróság különböző okokból instrumentálisan változtatja a bizonyítási sztenderdet, figyelembe véve a vizsgált kérdés érzékenységét, az általánosabb politikai érdekeket vagy azt a célt, hogy a jogi módosítás helyi hatásait enyhítse. ${ }^{70}$ Az Európai Bíróság azonban nem követeli meg a különböző tagállamok által az adott közpolitikában elfogadott intézkedések összehasonlítását. A Bíróság álláspontjának az a racionalitása, hogy a tagállamok hatáskörébe tartozik az elérendő közpolitikai célok meghatározása és a területükön elérendő védelmi szint meghatározása. Ebből kifolyóan az a tény, hogy az egyik tagállam enyhébb szabályokat határozott meg ugyanannak a közpolitikai célnak az elérésére, nem eredményezi szükségszerűen egy másik tagállam által bevezetett szigorúbb szabályok aránytalanságát és a szabadságok korlátozásának jogszerűtlenségét. ${ }^{71}$ Ezt az elvet azonban árnyalja az egyenértékủ védelem elve, amely szerint a fogadó tagállam köteles annak vizsgálatára, hogy ugyanazt a közérdekủ célt hogyan védi a származás állama, és hogy vajon az adott gazdasági szereplő a fogadó állam által támasztott követelményeknek eleget tett-e. ${ }^{72}$

Összességében az arányosság elvének való megfelelés jelentős terhet ró a tagállamok azon közpolitikájára és szabályozására, amely közérdekű (helyi érdekű) cél megvalósítását szolgálja, azonban ütközik a belső piac mint közös közpolitika céljaival. ${ }^{73} \mathrm{~A}$ túlzott korlátozások tilalma, a szükségesség bizonyítása és a legkevésbé korlátozó alternatíva alkalmazása a kiválasztott és a megjelölt közérdekủ cél elérésére a nemzeti közpolitikai választást aláveti a bírói kontrollnak, és általában szük választási lehetőséget enged a tagállami közpolitikai aktoroknak. ${ }^{74} \mathrm{~A}$ Bíróság joggyakorlatából eredő korlátozások ahhoz vezethetnek, amit a jogirodalom úgy nevezett, hogy „a közérdekủ érvek lényege felhígul” az európai közpolitikai térben. ${ }^{75}$

hozott ítélet, EU:C:2018:130; C-503/99. sz. Commission kontra Belgium ügyben 2002. június 4-én hozott ítélet, EU:C:2002:328.

${ }^{69}$ C-110/05. sz. Commission kontra Italy ügyben 2009. február 10-én hozott ítélet, EU:C:2009:66, 66. pont

${ }^{70}$ Lásd Shuibhne -Maci (56. lj.) 997.

${ }^{71}$ C-3/95.sz. Reisebüro Broede ügyben 1996. december 12-én hozott ítélet, EU:C:1996:487.

${ }^{72}$ C-340/89. sz. Irène Vlassopoulou kontra Ministerium für Justiz, Bundes- und Europaangelegenheiten Baden-Württemberg ügyben 1991. május 7-én hozott ítélet, EU:C:1991:193; C-458/08. sz. Commission kontra Portugal ügyben 2010. november 18-án hozott ítélet, EU:C:2010:692.

${ }^{73}$ Az arányosság elvéről lásd VARJu Márton - PAPP Mónika: „Member State economic patriotism and the law of the EU Single Market: Legitimate Control Through Proportionality?" in GeRőcs Tamás SZANYI Miklós (szerk.): Market liberalism and economic patriotism in the capitalist world-system (Cham: Palgrave Macmillan 2019) 127-151. https://doi.org/10.1007/978-3-030-05186-0_7.

${ }^{74}$ Davies (37. lj.).; Tor-Inge HARBo: „The function of the proportionality principle in EU law” European Law Journal 2010/2. 158-185. https://doi.org/10.1111/j.1468-0386.2009.00502.x; valamint lásd REICH (25. lj.).

${ }^{75}$ Lásd ShuibhNe (27. lj.) 300-301. 
A Bíróság a joggyakorlata következtében politikailag érzékeny konfliktusok és viták kereszttüzébe került, amelyek arról szólnak, hogy az Európai Unió rendszerében hol húzódik a tagállamok legitim közpolitika-alkotási tere. Bár a Bíróság előtti eljárások jogi kérdésekre koncentrálnak, és politikamentesek maradnak, addig a tagállamok döntően azért veszítik el az eljárást, mert az alkalmazott tagállami intézkedések nem győzik meg a Bíróságot arról, hogy a közpolitikai reakciójuk az elvártnak megfelelő pontosságú és intenzitású. A felmerülő tagállami érdekek fontossága és a tagállami közpolitika legitimitása szinte soha nem kérdőjeleződik meg, de a Bíróság szinte mindig képes rámutatni a vitatott intézkedés alternatíváját jelentő intézkedésre. A versenyző EU és tagállami érdekek közötti valódi mérlegelésre kizárólag kivételes jelleggel kerül sor. ${ }^{76}$

\subsection{AZ EURÓPAI BÍRÓSÁG VISSZAUTAL A NEMZETI BÍRÓSÁGRA (A DEFERENCIA JELENSÉGE)}

A fentiekből világossá vált, hogy a tagállami korlátozást értékelő fórum szerepe elsődleges fontosságú a tagállami közpolitikai és szabályozási autonómia határainak megrajzolásában. Az is nyilvánvaló, ez a fórum nem mindig az Európai Bíróság. Az előzetes döntéshozatali eljárásban az Európai Bíróság több kérdésben a tagállami bíróság feladatává teheti a végső döntés meghozatalát bizonyos kérdésekben: az arányosságot illetően például a végső vizsgálat a tények és az ügy körülményei alapján a nemzeti bíróságot terhelheti. ${ }^{77}$ Tridimas álláspontja szerint a Bíróság által gyakorolt előzetes döntéshozatali hatáskörben ez „egy alkotmányos szelepet jelent: az eljáró bírósági irányt szabályozza és meghatározza, hogy a tagállami közpolitikai választás felülvizsgálatát kizárólag az Európai Bíróság végzi-e el, vagy azt megosztja a nemzeti bíróságokkal."78 Ennek megfelelően a Bíróság a következő három módon dönthet: specifikus választ ad az előterjesztett kérdésekre, és nem hagy a tagállami bíróság számára mérlegelési mozgásteret, hanem egy előre elkészített megoldással a jogvitát is eldönti (a Bíróság megadja a jogvita végső megoldását); vagy az Európai Bíróság a nemzeti bíróságot csak iránymutatással látja el, hogy az hogyan döntse el a jogvitát (az Európai Bíróság iránymutató ítéletei); vagy a Bíróság olyan általánosan válaszolja meg az előzetes döntési kérdéseket, amelylyel tulajdonképpen a nemzeti bírósághoz utalja a jogértelmezési kérdés megválaszolását is (a Bíróság deferens a nemzeti bírósággal szemben).

Zglinski a deferenciának szintén három változatát különbözteti meg. Teljes deferencia esetén az Európai Bíróság semmilyen módon nem határozza meg a kimen-

${ }^{76}$ Lásd Davies (37. lj.).

77 Jan ZgLinski: „The rise of judicial deference: the margin of appreciation and decentralised judicial review in EU free movement law" Common Market Law Review 2018/5. 1341-1386. A magyar irodalomból lásd VÁRnAY Ernő: „Az Európai Unió Bírósága visszautal a magyar bírósághoz” Európai Tükör 2019/3. 23-33. https://doi.org/10.32559/et.2019.3.2.

78 Takis TRIDIMAS: „Constitutional review of member state action: the virtues and vices of an incomplete jurisdiction" International Journal of Constitutional Law 2011/3-4. 737-756. https://doi. org/10.1093/icon/morO52. 
tést és arányossági vizsgálatot a nemzeti bíróság számára (teljes visszautalás), másrészről az Európai Bíróság a nemzeti bíróság feladatává teszi a kimentés és arányosság vizsgálatát, de meghatározza, hogy az hogyan végzendő el (visszautalás iránymutatással), harmadrészt az Európai Bíróság a nemzeti bíróság feladatává teheti a kimentés és arányosság vizsgálatát, de maga is prima facie értékelést nyújt arról a nemzeti bíróságnak (ezt Zglinski tendencia-visszautalásnak nevezi, ami arra utal, hogy az Európai Bíróság elemzése nyilván befolyásolni fogja a nemzeti bíróság értékelését). ${ }^{79}$

A deferencia jellegét és ezáltal a nemzeti bíróság mérlegelési jogkörének terjedelmét álláspontom szerint több faktor is motiválhatja: az Európai Bíróságnak nincs hatáskörében tényintenzív felülvizsgálatot folytatni az előzetes döntéshozatali eljárásban, vagy a tagállami intézkedés céljait nem lehet bizonyossággal megállapítani. Utóbbi esetben a tagállamnak a nemzeti bíróságot kell meggyőznie arról, hogy az intézkedés céljai szükségessé teszik a korlátozást, és ezért az jogszerű az EU-jog alapján. Más esetekben azonban az Európai Bíróság már nemcsak tények, hanem a nemzeti jogi és szabályozási környezet ismeretével rendelkező nemzeti bíróságra bízza egy-egy belső piaci korlátozás szükségességének és arányosságának értelmezését. ${ }^{80}$

Az európai bírósági rendszeren belüli feladatmegosztás jeleként is értékelhető, ha az Európai Bíróság jogértelmezési és ezzel mérlegelési mozgásteret enged a nemzeti bíróságoknak. Másrészt a piaci integráció elérésének érzékelhető veszélyét is magában hordozhatja a túlzott deferencia. A tagállami kormányok a nemzeti bírák „közpolitikai beavatkozását” szkeptikusan kezelhetik, megkérdőjelezhetik azok legitimitását, mivel egyes ítéleteknek lényeges politikai és társadalmi következményei is lehetnek. Az arányossági vizsgálatban összemosódhat egyrészről a politikai választás bírósági felülvizsgálata, másrészről az, hogy a vizsgálatban a bíróság helyettesíti-e sajátjával a tagállami politikai választást, esetleg új értékelést hozva be az ügybe. Ez a közpolitikai aktorok közötti feszültséget, beleértve a nemzeti bíróságokat és az Európai Bíróságot is, tovább növelheti. ${ }^{81}$ Barnard álláspontja szerint a nemzeti bíróságok általában a tagállami szabályozás fenntartására törekednek, amenynyiben hatáskörrel rendelkeznek kardinális kérdésekben. ${ }^{82}$ Tridimas arra is felhívja a figyelmet, hogy amennyiben az Európai Bíróság a jogvita eldöntője, ez nem jelenti szükségszerűen a Közösség érdekének elfogadását: a Bíróság a nemzeti alkotmányos közösség védelmében fenntarthatja a nemzeti intézkedés jogszerűségét és az ítéletének politikai érzékenysége nincs mindig közvetlen összefüggésben az ítéletének specifikus jellegével. ${ }^{83}$

Lehetetlen általános következtetéseket levonni a Bíróság beavatkozásának jellegéről és azon kérdést illetően is, hogy a nemzeti bíróságoktól milyen beavatkozás

${ }^{79}$ Lásd Zglinski (77. lj.) 1347-1351.

${ }^{80}$ Néhány magyar ügyről elemzést ad VÁRNAY Ernő: „Az Európai Unió Bírósága visszautal a nemzeti bírósághoz” Európai Tükör 2019/3. 23-33.

${ }^{81}$ Niamh Nic Shuibhne - Marsela MACI: „Proving public interest: the growing impact of evidence in free movement case law" Common Market Law Review 2013/4. 965-1006., 991.

82 Lásd BARNARD (39. lj.) 296.

${ }^{83}$ Lásd Tridimas (78. lj.) 753. 
várható el, mivel a Bíróság számos ítéletet hozott a négy gazdasági szabadsággal kapcsolatban és a Bíróság hozzáállása is különböző volt. ${ }^{84} \mathrm{Az}$ arányossági teszttel összefüggésben például a Bíróság elismerte, hogy a potenciális alternatív, azaz kevésbé korlátozó intézkedést tekintve „nem lehet a tagállamtól megkövetelni, hogy bizonyossággal bizonyítsa, hogy semmilyen más elképzelhető intézkedés nem tudná ugyanazt a célt ugyanolyan feltételekkel biztosítani”. ${ }^{85}$ A tagállamoktól nem tagadható meg annak lehetősége sem, hogy a közpolitikai célt olyan általános és egyszerű szabályok bevezetése útján érjék el, amelyeket a hatóságok könnyen kezelhetnek és ellenőrizhetnek. ${ }^{86}$ Más ügyekben a Bíróság megtagadta annak elfogadását, hogy a tagállamok jogi vagy adminisztratív nehézségekkel indokolják a kereskedelemkorlátozás bevezetésének szükségességét. Általában több tényezőtől is függ és nehéz előre megjósolni, hogy a Bíróság milyen teret enged a tagállami korlátozás kimentésének egy szigorúbb vagy egy enyhébb arányossági teszt alkalmazásával. A belső piaci joggyakorlat koherenciája ezért igen alacsony szintű, és a tagállamok számára nehézséget jelenthet annak előrelátása, hogy szabályozásuk jogszerű-e. Ez azt is eredményezi, hogy összetett tagállami közpolitikák meghatározása bonyolulttá válhat, főként olyan területeken, amelyeken nincs másodlagos EU-szabályozás.

Reich egy sor ítéletet azonosított, amelyben a Bíróság az arányosság vizsgálatán keresztül kvázi törvényalkotási szerepet töltött be az ő szóhasználata szerint. ${ }^{87}$ Például a Centros, ${ }^{88}$ Cadburry Schweppes, ${ }^{89}$ és Gybrechts ${ }^{90}$ ügyekben úgy tủnik, hogy a Bíróság lényegesen gyengítette és korlátozta a tagállamok lehetőségét olyan fontos közpolitikai célok elérésében, mint a fogyasztóvédelem és a hitelezők védelme. Reich érve szerint pozitív EU-közpolitika (jogharmonizáció) hiányában a Bíróságnak nem lett volna szabad kvázi törvényhozóként beavatkoznia. Álláspontja szerint

${ }^{84}$ A Bíróság egyes szabadságok esetében különböző értelmezési trendeket is kialakított.

${ }^{85}$ C-110/05. sz. Commission kontra Italy ügyben 2009. február 10-én hozott ítélet, EU:C:2009:66, 66. pont. Később a Bíróság megerősítette például a C-333/14. sz. Scotch Whisky Association és társai kontra The Lord Advocate és The Advocate General for Scotland ügyben 2015. december 23-án hozott ítéletében. 55. pont: „ez a bizonyítási teher nem terjedhet annak megköveteléséig, hogy az MPU-hoz hasonló intézkedés előírása esetén az illetékes nemzeti hatóságok kétséget kizáróan bizonyítsák, hogy semmilyen más elképzelhető intézkedés nem teszi lehetővé a követett jogszerű célkitűzés ugyanezen feltételek melletti megvalósítását."

${ }^{86}$ Lásd főként a C-110/05. sz. Commission kontra Italy ügyben 2009. február 10-én hozott ítéletet, EU:C:2009:66, 65. pont. Kérdéses, hogy ezt a megállapítást a Bíróság később követte-e. Később ezt a jogértelmezést a Bíróság követte. Lásd például a C-126/15. sz. Bizottság kontra Portugál Köztársaság ügyben 2017. június 29-én hozott ítélet 84. pontját: „Márpedig a Bíróság ítélkezési gyakorlata szerint nem tagadható meg a tagállamoktól annak lehetősége, hogy az olyan jogszerű célkitűzéseket, mint az adókijátszás és az adóelkerülés elleni küzdelem, valamint az egészség, illetve a rendes és tisztességes verseny védelme, könnyen alkalmazható és ellenőrizhető szabályok bevezetésével érjék el."

87 Lásd Reich (25. lj.).

${ }^{88}$ C-212/97. sz. Centros Ltd. kontra Erhvervs- og Selskabsstyrelsen ügyben 1999. március 1-jén hozott itélet, EU:C:1999:126.

${ }^{89}$ C-196/04. sz. Cadbury Schweppes plc and Cadbury Schweppes Overseas Ltd kontra Commissioners of Inland Revenue ügyben 2006. szeptember 12-én hozott ítélet, EU:C:2006:544.

${ }^{90}$ C-205/07. sz. Lodewijk Gysbrechts and Santurel Inter BVBA ügyben 2008. december 16-án hozott ítélet, EU:C:2008:730. 
a Bíróságnak önmérsékletet kellett volna tanúsítania, föként azokon a területeken, amelyeken fontos tagállami közpolitikai érdekek forognak kockán, és a tagállamok nem találtak közös közpolitikai alapot a cselekvésre. ${ }^{91}$ Reichhoz hasonlóan Thym is állást foglalt a közpolitikai kivételek értelmezéséről, és figyelmeztetett, hogy a Bíróságnak gondosan kell eljárnia a kivételek alkalmazásakor, mivel azoknak fontos kulturális, társadalmi és erkölcsi következményei lehetnek. Különösen a „marihuána, pornográfia és szerencsejátékok példázzák ezt a széles alkalmazási kört. Ezeket a kérdéseket nem kell egységesen szabályozni egy belső piacon sem; ehhez hasonlóan nem kell teljes mértékben harmonizálni egy szupranacionális politikai unióban, amelynek megvalósítására az EU törekszik”. ${ }^{92}$ A jogirodalom más képviselői árnyaltabb hozzáállást sürgettek, és felvetették annak szükségszerüségét, hogy az európai és tagállami szabályok tényleges kontextusát is figyelembe kell venni. ${ }^{93}$ Lehet, hogy a kontextualizálás az, amely az európai integráció több évtizedén keresztül kifejlődött komplex és sokszor inkoherens esetjog megértésében segíthet. A strukturáltabb értékelés jelentheti egyrészt a tagállamok és az Unió közötti vertikális hatáskörmegosztás figyelembevételét és ezután a négy gazdasági szabadság rendelkezései hatásainak kontextualizálását specifikus és egyedi közpolitikai hatáskörökre. ${ }^{94}$ Másrészt a négy gazdasági szabadságra vonatkozó rendelkezések alkotmányos minőségének értékelésében tekintettel kell lenni a különböző közpolitikai területek normatív céljaira, mivel azok eléggé divergálók, és az adott közpolitikai szektorra jellemzők. ${ }^{95}$ A fentieket figyelembe véve a tagállamok négy gazdasági szabadság alapján rendelkezésére álló közpolitikai mozgásterének értékelésében elkülönítjük a különböző közpolitikai területeket, úgymint szerencsejáték, közegészség, közúti biztonság, közerkölcs, és különbözően határozzuk meg az EU-jog alapján potenciálisan fennálló kötelezettségeket is.

Zglinski az 1974 és 2014 közötti előzetes döntéshozatali eljárásokban vizsgálva az általános deferenciát, arra az eredményre jutott, hogy a deferens ítéletek száma egyre nőtt az integráció során. Míg 1974-ben az előzetes döntések kevesebb mint 10\%-ában alkalmazta ezt a technikát az Európai Bíróság, addig 2014-re ez az arány már 30\% fölé kúszott. ${ }^{96}$

Zglinski vizsgálata szerint a szükségesség és arányosság vizsgálatának kérdésében az Európai Bíróság a belső piaci esetek még nagyobb, 48\%-ában alkalmazott deferenciát, azaz nem maga végezte el a szükségességi és arányossági tesztet. ${ }^{97}$

91 Lásd Reich (25. lj.) 185.

92 Daniel Thyм: „The constitutional dimension of public policy exceptions” in Panos Koutrakos - Niamh Nic Shuibhne-Phil Syrpis (szerk.): Exceptions from EU free movement law. Derogation, justification and proportionality (Oxford: Hart Publishing, 2016) 171-189., 185.

${ }_{93}$ Pedro Caro De Sousa: The European fundamental freedoms. A contextual approach. (Oxford: Oxford University Press, 2015).

${ }^{94}$ Florian DE WiTTE: „The constitutional quality of the free movement provisions: looking for context in the case law on Article 56 TFEU” European Law Review 2017/3. 313-338., 313-314.

${ }^{95}$ DE WitTe (94. lj.) 314.

${ }^{96}$ Lásd Zglinski (77. lj.) 1355.

${ }^{97}$ Lásd Zglinski (77. lj.) 1375. 


\subsection{A JOGGYAKORLAT HATÁSAI}

A tagállami közpolitikai és szabályozási választások szigorú európai bírósági elbírálása azon általános következtetés levonását teszi lehetővé, hogy az EU alkotmányos rendszerében a belső piac nagyobb értékű, mint a párhuzamos vagy versengő tagállami közpolitikák. Claes szerint a mérlegelés eredménye általában az európai integráció irányába billen el. ${ }^{98}$ Szerkezeti ellentmondás van ugyanis az EU gazdasági alkotmányába kódolva, ${ }^{99}$ amelynek széles körű kritikája szerint a gazdasági szereplők négy szabadságból eredő egyéni jogai előnyösebb jogi elbírálást élveznek a Bizottság jogérvényesítésében vagy a nemzeti bíróságok előtt a nemzetállamok nem gazdasági jellegű és általában kollektív érdekeivel és értékeivel szemben. Ennek a komoly politikai és alkotmányos problémának a megválaszolására inkább alkalmas az EU másodlagos jogalkotása, mint az EU elsődleges jogának bírósági alkalmazása. A jogalkotás során az EU-jogalkotó meghatározhatja a piacteremtés és piaci korrekciók megfelelő arányát, amelynek során szerkezeti vagy normatív indokok nem korlátozzák. ${ }^{100} \mathrm{Az}$ EU másodlagos jogalkotása szükségszerűen korlátozza a Bíróság beavatkozási terét is, és neki az uniós szabályok értelmezésének hatáskörét „egy olyan széles keret meghúzásával kellene gyakorolnia, amelyen belül a belső piaci hatáskör gyakorlása nem jár a demokratikus megfontolások túlzott korlátozásával. A Bíróságnak a belső piaci jog egyes rendelkezéseit a jogalkotó céljának megfelelő szabályozási megfontolások fényében kellene értelmeznie."101

\subsection{GAZDASÁGON KÍVÜLI ÉRTÉKEK ÉS NORMÁK BEILLESZTÉSE A GAZDASÁGI SZABADSÁGOKBA (MAINSTREAMING)}

A piaci integráció szűken meghatározott céljaival versengő célkitűzések figyelembevételének másik módja az Unió által meghatározott általános vagy specifikusabb célok és feladatok integrációja az EU belső piaci szabályozásába vagy az Európai Bíróság belső piaci jogalkalmazásába. Mint fentebb említettem, a tagállamok több integrációs klauzulát építettek be a Szerződések szövegébe, mint a foglalkoztatás magas szintjének előmozdítása, a diszkrimináció elleni küzdelem, a fenntartható fejlődés, fogyasztóvédelem elősegítése vagy az általános gazdasági érdekű szolgáltatások teljesítésének előmozdítása. Az EUMSZ 9. cikkébe a Lisszaboni Szerződés által beillesztett szociális védelem horizontális klauzulája a belső piac szempontjából

98 Monica Claes: „The European Union, its Member States and their citizens” in Dorota LeczykIEwicz - Stephen WeatheriLl (szerk.): The involvement of EU Law in private law relationships (Oxford: Hart Publishing 2013) 29-52., 51.

99 Тнум (92. lj.) 176.

${ }^{100}$ Bruno DE WiTTE: „A competence to protect. The pursuit of non-market aims through internal market legislation” in Phil SYRPIS (szerk.): The judiciary, the legislature and the EU internal market (Cambridge: Cambridge University Press 2011) 25-46., 27. https://doi.org/10.1017/ CBO9780511845680.004.

${ }^{101}$ Lásd DE WitTe (100. lj.) 27. 
meghatározó jelentőségű. ${ }^{102}$ Schiek szerint Lisszabon után a szociális integrációt nem lehet többé elválasztani a piaci integrációtól, mivel az a szociálpolitikát megosztott hatáskörként kategorizálta, és az Unió szociális alapjogokban bővelkedő Alapjogi Chartáját kötelezővé tette. ${ }^{103}$ Schiek arra is rávilágított, hogy többnyire csak a belső piac megvalósításához áll rendelkezésre egy adott jogi keretrendszer. ${ }^{104} \mathrm{Az}$ ő álláspontja szerint azonban „az új minőséggel rendelkező új alkotmányos jogok kizárják, hogy a közvetlen hatályú gazdasági szabadságokat és versenyjogi szabályokat úgy értelmezzék, amelyek korlátozzák a nemzeti és transznacionális megoldások alkalmazását." ${ }^{105}$ Schiek szerint az Európai Bíróságnak alapvető szabadságokra vonatkozó nézőpontját egészen radikálisan kellene megváltoztatnia.

Általánosan elfogadott jogirodalmi vélemény szerint ${ }^{106}$ a Bíróság nem szentel megfelelő figyelmet a mainstreaming klauzulának és a Lisszaboni Szerződéssel bevezetett más módosításoknak, valószínűleg azért, mert az EU politikai intézményei feladatának tekinti ezt.

\section{A PIAC ÉS A SZOCIÁlIS SZFÉRA KÖZÖTTI EGYENSÚLYTALANSÁGOK}

Ahogyan korábban már említettük, a gazdasági szabadságok és a nemzeti szociálpolitika közötti egymásra hatás a nemzeti érdekek megvalósítását célzó tagállami kormányok nézőpontjából különös feszültségeket teremtett. Az EU hatásköre ebben a közpolitikai szegmensben korlátozott, és a gazdasági szabadságok alkalmazásának deregulatív hatását valószínủleg nem ellensúlyozza az EU pozitív másodlagos jogalkotása. A piaci integráció által okozott szociális konfliktusokat a belső piaci jog marginalizálta. ${ }^{107}$ Kingreen álláspontja szerint „az állandóan előrenyomuló negatív integráció és a kétségtelenül stagnáló pozitív integráció, például a szociálpolitikai terén, aszimmetriája végül a közjóléti rendszerre vonatkozó felelősség szétforgá-

${ }^{102}$ Lásd ebben a témában a C-544/10.sz. Deutsches Weintor ügyben 2012. szeptember 6-án hozott ítélet, EU:C:2012:526, 49. pont.

${ }^{103}$ Dagmar Schiek: „Re-embedding economic and social constitutionalism: normative perspectives for the EU" in Dagmar ScHIEK - Ulrike LIEBERT - Hildegard SchneIder (szerk.): European economic and social constitutionalism after the Treaty of Lisbon (Cambridge: Cambridge University Press 2011) 17-46, 42. https://doi.org/10.1017/CBO9780511835193.004.

${ }^{104}$ Lásd Schiek (103. lj.) 42.

${ }^{105}$ Lásd Schiek (103.lj.) 45-46.

${ }^{106}$ Evangelia Psychogiopoulou: Integration of cultural considerations in European Union law and policies (Leiden, Boston: Martinus Nijhoff 2008) https://doi.org/10.1163/ej.9789004162396.i-402; Niamh Nic Shuibhne: „Primary laws: judging free movement restrictions after Lisbon” in Panos Koutrakos - Niamh Nic Shuibhne - Phil Syrpis (szerk.): Exceptions from EU free movement law. Derogation, justification and proportionality (Oxford: Hart Publishing 2016) 297-318.; Hans VEDDER: „Integrating rather than juxtaposing environmental policy and the internal market” in Panos Koutrakos - Jukka SnEll (szerk.): The law of the EU's internal market (Cheltenham: Edward Elgar Publishing 2017) 171-190. https://doi.org/10.4337/9781783478101.00015.

${ }^{107}$ Marco DANI: „Rehabilitating social conflicts” European Law Journal 2012/5. 621-643. https://doi. org/10.1111/j.1468-0386.2012.00621.x. 
csolódását okozhatja. Ez a nemzetállamok krízisét fejezi ki, amelyet a kormányzó képesség csökkenése eredményez, és emellett a nemzetköziesedés is kihívások elé állítja a nemzetállamokat."108 Többen is sokszor szorgalmazták a társadalmi és gazdasági célok közötti egyensúly megteremtését, ${ }^{109}$ és felhívták a Bíróságot, hogy a piaci integráció és torzításmentes verseny, valamint a szociális célok egyensúlyát állítsa vissza, különösen azon szociális célok vonatkozásában, amelyek fokozatosan megjelentek a Szerződésekben is. A Szerződés általános elveinek szintjén értelmes egyensúlyban állnak a gazdasági és szociális célok, anélkül, hogy a gazdasági célok előnyt élveznének. ${ }^{110} \mathrm{Az}$ uniós célok kapcsolatában nyilvánvaló elmozdulás következett be, amikor az európai integráció általános társadalmi-gazdasági céljaként a magas versenyképességű szociális piacgazdaságot jelölték meg. ${ }^{111}$ Devroe és Cleynenbreugel álláspontja szerint továbbá a jelenlegi elsődleges jogi felépítés vagy úgynevezett EU gazdasági alkotmány „nem jelent mentséget sem arra, hogy a szociális integráció nem fejlődött tovább, sem arra, hogy szétkapcsolják a szociális és gazdasági integrációt.”112 Ezenkívül véleményük szerint „a nyitott gazdasági alkotmányban helye van az értékek széles körü beemelésének értelmezés által." ${ }^{113}$ Kritikus hangok arra hívták fel a figyelmet, hogy a Szerződés szövegéből adódó lehetőségek ellenére az Európai Bíróság a gazdasági szabadságok alkalmazásával felborította az egyensúlyt a belső piac szociális és gazdasági céljai között, és veszélybe sodorta a szociális védelem nemzeti rendszerét. A szabad mozgásra és nemzeti egészségügyi rendszerekre vonatkozó ítélkezési gyakorlatot különösen az jellemzi, hogy

${ }^{108}$ Thorsten Kingreen: „Fundamental freedoms” in Armin von BogdAndy - Jürgen BAST (szerk.): Principles of European constitutional law (Oxford: Hart Publishing, CH Beck, Nomos, 2010) 515549., 527-528. https://doi.org/10.1017/S1574019616000407.

${ }^{109}$ Sacha GARBEN: „The Constitutional (Im)balance between »the Market « and »the Social $\ll$ in the European Union” European Constitutional Law Review 2017/1. 23-61.

${ }^{110}$ Lásd az EUSZ 3. cikk (1) bekezdését.

${ }^{111}$ Christian Joerges - Florian RöDL: „The "Social Market Economy" as Europe's social Model?” EUI Working Paper LAW 2004/8.; Loïc AzoulaI: „The Court of Justice and the social market economy: The emergence of an ideal and the conditions for its realization" Common Market Law Review 2008/5. 1335-1356.; Fritz W. ScharPF: „The asymmetry of European integration, or why the EU cannot be a »social market economy «" Socio-Economic Review 2010/1. 211-250. https://doi.org/10.1093/ser/mwp031; Dragana DAMJANovic: „The EU market rules as social market rules: why the EU can be a social market economy" Common Market Law Review 2013/6. 1685-1717.; Kaarlo TuORI: „European social constitution: between solidarity and access justice” in Kai PuRnhagen - Peter RotT (szerk.): Varieties of European economic law and regulation (Berlin: Springer Publishing 2014) 371-400. https://doi.org/10.1007/978-3-319-04903-8_18; Florian DE WiтTE: „The architecture of the EU's social market economy” in Panos Koutrakos - Jukka SNELL (szerk.): Research handbook on the law of the EU's internal market (Cheltenham: Edward Elgar Publishing 2017) 117-138. https://doi.org/10.4337/9781783478101.00013.

${ }^{112}$ Wouter Devroe - Pieter Van Cleynenbreugel: „Observations on economic governance and the search for a European economic constitution" in Dagmar SchiEK - Ulrike LieberT - Hildegard SCHNEIDER (szerk.): European economic and social constitutionalism after the Treaty of Lisbon (Cambridge: Cambridge University Press 2011) 96-122., 120. https://doi.org/10.1017/ CBO9780511835193.007.

${ }^{113}$ Wouter Devroe - Pieter VAn Cleynenbreugel: „Observations on economic governance and the search for a European economic constitution" in Dagmar SchIEK - Ulrike LIEBERT - Hildegard SCHNEIDER (szerk.): European economic and social constitutionalism after the Treaty of Lisbon (Cambridge: Cambridge University Press 2011) 96-122, 120. 
a nemzeti jóléti rendszereket elszakítja a nemzetállamoktól és nemzeti területektől, így aláásva azok szolidaritási alapjait. ${ }^{114}$

Mint fentebb már kifejtettük, a Szerződésben szereplő, szociális politikára vonatkozó mainstreaming klauzulák mindez idáig nem változtatták meg a bírósági értelmezés irányát. A tagállami közpolitikai intézkedések alávetése a korlátozások kimentésére vonatkozó sztenderdnek (bizonyítási teher, szigorú szükségességi teszt és arányossági kritérium) mély deregularizáció veszélyével járhat a nemzeti szociális védelmi jogszabályokra és munkaügyi sztenderdekre, anélkül, hogy az EU-nak hatásköre vagy valós politikai-döntéshozatali lehetősége lenne arra, hogy a deregularizáció következtében eltűnő nemzeti szabályokat közös szociális szabályokkal helyettesítse. Ebben az értelemben az Európai Bíróságot támadó kritikák középpontjában az áll, hogy a Bíróság védi a gazdasági integráció neoliberális értékeit, és nem eléggé érzékeny a szélesebb értelemben vett társadalmi problémákra. ${ }^{115}$ Bár a neoliberális értékek a gazdasági és pénzügyi válságban megkérdőjeleződtek, a torzításmentes versenynek és a deregulált piacon zajló szabad kereskedelemnek a folyamatos hangsúlyozása a neoliberális elvek megnyilvánulásának tủnik, amelyeket a Bíróság hajlandó előnyben részesíteni az állam-vállalkozások-társadalom kapcsolatát jellemző sajátos nemzeti berendezkedéssel szemben.

Davies joggal hangsúlyozta, hogy a belső piaci jogalkalmazásban a Bíróság a kérdéses tranzakcióban részt vevő felek viszonyát vizsgálja, és nagyrészt figyelmen kívül hagyja a tranzakció aktuális társadalmi beágyazottságát, amely viszont jelentős problémát okoz, mivel a jogalkalmazás a legalapvetőbb változást a nemzeti élet szövedékében okozza, ${ }^{116}$ az egyének közötti szélesebb értelemben vett társadalmi kapcsolatokban, valamint az egyén és állam kapcsolatában. ${ }^{117}$ Ezzel kapcsolatban de Witte vetette fel, hogy a szociális piacgazdaság megteremtésének kutatását a nemzeti (szociális) hatáskörök elválasztásával és a piac szociális beágyazottságának megteremtésével lehet megvalósítani. ${ }^{118}$ A megvalósítás érdekében meg kell változtatni a gazdasági szabadságok hatályának jelenlegi értelmezését vagy az arányosság bizonyítási terhének megfordításával, ${ }^{119}$ az EUMSZ 9. cikkében szereplő horizontális klauzula erőteljesebb értelmezésével, vagy az EU Alapjogi Charta hatályának kiterjesztésével. Előremutató lépés lenne a horizontális klauzulának nagyobb szerepet tulajdonítani, amelyet pontosan azzal a szándékkal illesztettek be a Szerződésbe, hogy ellensúlyozzák a belső piaci célkitűzést. A klauzula olyan átívelő jogi kötele-

${ }^{114}$ Kaarlo Tuori: „European social constitution: between solidarity and access justice” in Kai PuRnHAGEN Peter Rotт (szerk.): Varieties of European economic law and regulation (Berlin: Springer Publishing 2014) 371-400., 388. és 399., lásd még Vassilis Hatzopoulos: „Killing national health and insurance systems but healing patients? The European market for health care services after the judgments of the ECJ in Van Braekel and Peerbooms" Common Market Law Review 2002/4. 683-729.

${ }^{115}$ Lásd ScharpF (111. lj.), DE WitTe (111. lj.). A neoliberalizmusról általában és különösen a gazdasági válság után betöltött szerepéröl lásd Vivien A. ScHмidT - Mark THATcher (szerk.): Resilient liberalism in Europe's political economy (Cambridge: Cambridge University Press 2013) https://doi. org/10.1017/CBO9781139857086.

${ }^{116}$ Texture of national life.

${ }^{117}$ Lásd Davies (37. lj.) 290.

${ }^{118}$ Lásd DE WiTTE (111. lj.) 138.

${ }^{119}$ Lásd ebben az értelemben Damjanovic (111. lj.). 
zettséget teremt, amely az Uniót és intézményeit is érinti, és amelyet a Bíróságnak figyelembe kellene vennie a belső piac jellegének értelmezésében.

Schiek szerint az EU Alapjogi Chartájának tulajdonítandó nagyobb jogi súly potenciálisan megváltoztathatja a játékszabályokat. ${ }^{120}$ Álláspontja szerint a Charta bevezetése után a belső piac alkotmányosan meghatározottá vált mind a szociális, mind a gazdasági jogok által egy olyan rendszeren belül, amelyben a két típusú jog kapcsolata nem kizárólagosan ellentétes jellegű. ${ }^{121}$ Felfogásában a szociális piacgazdaság megvalósításának követelményét az EU Chartához kell kapcsolni, és ennek megfelelően kell az Európai Bíróságnak a belső piaci jogértelmezését megváltoztatnia. Ezen túl Schiek szerint a gazdasági szabadságok megegyeznek a Chartában szereplő vállalkozás szabadságával, és ezen az alapon érvelt amellett, hogy a gazdasági szabadságok és szociális jogok közötti konfliktusokat úgy kell feloldani mint a Charta szabadságai és jogai között meglévőket, döntően a kölcsönös maximalizáció segítségével. ${ }^{122}$ Mivel a Chartában a 16. cikk szerinti vállalkozás szabadságát az uniós joggal, valamint a nemzeti jogszabályokkal és gyakorlatokkal összhangban kell elismerni, továbbá a tagállami jog szociális és munkavédelmi szabályokat tartalmaz, ezért az ő következtetése szerint a szabadságot nem is korlátozza a tagállami foglalkoztatási szabályok puszta alkalmazása. ${ }^{123}$ Megoldásával megfelelően lehet biztosítani a tagállami szociális politika területén fennálló tagállami hatáskörök, valamint a szociális védelem nemzeti rendszereiben rejlő szerkezeti, szervezési és történelmi különbségek védelmét.

$\mathrm{Az}$ irodalomban is mélységeiben tárgyalt téma a belső piaci joggyakorlat nemzeti szinten jelentkező hatásai korlátozásának lehetősége és a tagállamok közpolitika-alkotási autonómiájának megvédése. Különböző javaslatok születtek arra, hogy az alapvető szabadságok egyre jobban kiterjesztett hatályából keletkező problémákat hogyan lehetne kezelni, és a tagállamok közérdekű kimentéseinek sikerességét biztosítani. A javaslatok a kismértékủ bírói gyakorlat módosításától egészen drasztikus változtatásokig terjednek, amelyek már a belső piaci szabályok alkotmányos helyzetének teljes újragondolását tartalmazzák. Az egyik legjelentősebb kritikus hang Fritz Scharpf, aki már régóta elégedetlenségét fejezte ki a negatív és pozitív integráció aszimmetrikus kapcsolatával a tagállami szociális politika vonatkozásában. A pénzügyi és gazdasági válság után napvilágot látó írásaiban annak a megváltoztatását javasolta, hogy a belső piac az európai gazdasági alkotmány részét képezze, és a gazdasági szabadságok, valamint a tagállami szociálpolitikák közötti konfliktusok politikai térbe való visszahelyezését javasolta. ${ }^{124}$ Nagyon erőteljesen

\footnotetext{
${ }^{120}$ Potential game-changer.

${ }^{121}$ Dagmar SchieK: „Towards more resilience for a social EU - the constitutionally conditioned internal market" European Constitutional Review 2017/4. 611-640, 613. https://doi.org/10.1017/ S1574019617000311.

${ }^{122}$ Lásd Schiek (121. lj.) 629. Ő a mutual maximisation kifejezést használja.

${ }^{123}$ Lásd SchieK (121. lj.) 628.

${ }^{124}$ Fritz W. ScharpF: „After the crash: A perspective on multilevel European democracy” European Law Journal 2015. 21: 384-405., 401. https://doi.org/10.1111/eulj.12127, lásd még Dieter GRImm: „The democratic costs of constitutionalisation: the European case” European Law Journal 2015/4. 460-473, 473. https://doi.org/10.1111/eulj.12139.
} 
érvelt a Szerződés rendelkezéseiből adódó és a Bíróság joggyakorlata által felerősített negatív integrációs folyamatok ellensúlyozása mellett, mégpedig EU-szintű, politikai folyamatokban generált jogharmonizáció megalkotásával. Álláspontja szerint a politikai szereplők így kerülhetik el a Bíróság kiterjesztő jogértelmezését, és elgördíthetik a tagállamok politikai mozgásterét korlátozó jogi akadályokat. ${ }^{125}$

Scharpf természetesen azt is elismerte, hogy a megfelelő tartalmú pozitív integráció megvalósításának lehetőségét nagyban behatárolja a minősített többségű szavazás és az EU döntéshozatali rendszerében meglévő több vétójátékos jelenléte (főként az Európai Parlament és az Európai Bizottság), és ennél is erőteljesebben a tagállami érdekek heterogenitása (például a régi és új tagállamok érdekeinek különbsége, a liberális és szociális piacgazdaságú tagállamok érdekei, a hitelező és adós tagállamok érdekeinek eltérése az eurózónában). ${ }^{126}$

Szintén Scharpf írta le, hogy „nem volt és nincs gyakorlatilag semmilyen esély arra, hogy a közösségi módszerre épülő európai törvényhozás kijavíthatná a negatív integráció és bírói jogalkotás liberalizációs hatását. Ezért észszerütlen a középbaloldali, Európa-párti politikai pártoktól és szakszervezetektől azt várni, hogy az európai szintű politikai fellépés értelmes „európai szociális modellhez” vezetne el, vagy hogy megvédenék az EU-tagállamok jelenlegi szociális piacgazdaságait a tagállamok közötti verseny nyomásától vagy a globális tőke hatásától."127

A nála kevésbé radikális javaslatok a joggyakorlatra fókuszáltak, és a megoldást a bírói jogértelmezés módosításában keresik.

Az egyik ilyen javaslat szerint a tagállamok közötti kereskedelem korlátozása fogalom megszorító értelmezéséhez kellene visszatérnie a Bíróságnak, és a vezérelvet a diszkrimináció vagy protekcionizmus szolgáltatná a jogszerű és jogszerűtlen korlátozások szétválasztásánál. ${ }^{128}$

Davies előterjesztése egyenesen arra irányul, hogy a gazdasági szabadságok hatályának és így a belső piac eszméjét sértő nemzeti intézkedések körének korlátozásával csökkenne annak a szükségessége, hogy a tagállamoknak kelljen a korlátozásaikat ellentmondásos és frusztráló módon igazolni, és ezzel azokat potenciálisan túlzott mértékủ bírói vizsgálatnak kitenni. ${ }^{129}$ Érvelésében a piacra lépési korlátozás vizsgálatának jogi tesztje azzal a hatással jár, hogy a bírói elemzés nem a tagállamok közötti kereskedelem védelmére irányul, hanem a versenypiaci helyzet torzítására. ${ }^{130}$

${ }^{125}$ Lásd Scharpf (124. lj.) 401.

${ }^{126}$ Lásd ScharpF (124. lj.) 387.

${ }^{127}$ Lásd Scharpf (124. lj.) 387.

${ }^{128}$ Sue ArRowsmith: „Rethinking the approach to economic justifications under the EU's free movement rules" Current Legal Problems 2015/1. 307-365. https://doi.org/10.1093/clp/cuv011, Jukka SNELL: „Economic justifications and the role of the state” in Panos Koutrakos - Niamh Nic Shuibhne - Phil Syrpis (szerk.): Exceptions from EU free movement law. Derogation, justification and proportionality (Oxford: Hart Publishing 2016) 12-31.

${ }^{129}$ Gareth DAviEs: „Between market access and discrimination: free movement as a right to fair conditions of competition" in Panos Koutrakos - Jukka Snell (szerk.): The law of the EU's internal market (Cheltenham: Edward Elgar Publishing 2017) 13-28., 16. https://doi.org/10.4337/978178 3478101.00007.

${ }^{130}$ Lásd Davies (129. lj.) 20-22. Lásd a Bíróság C-428/12. sz. ügyben 2014. április 3-án a Bizottság 
Ezzel a Bíróság Davies álláspontja szerint kényelmesebb helyzetbe került, hiszen a piacra jutási korlátozás/versenytorzítás bizonyítása könnyebb, mint annak bizonyítása, hogy protekcionista hatása van-e az intézkedésnek, mivel az lassú, költséges és bonyolult. ${ }^{131}$ Davies is sürgette a piaci korlátozás koncepciójának tisztázását, és a határainak kijelölését szorgalmazta. Ezen túl javasolta, hogy a gazdasági szabadságoknak a Bíróság szorosabb értelmet tulajdonítson, mert így válik lehetővé a tagállamok számára, hogy a nemzeti érdeket szolgáló szabályozási közpolitikáik, különösen a szociális politika EU-jog által meghatározott sorsát előre megtervezhetően lássák. ${ }^{132}$

\section{KONKLÚZIÓ}

A belső piac az államok közötti (kormányközi) közpolitika sajátos formája Európában, amelynek a Szerződésben szereplő minimalista jellegű tartalmát nagyban befolyásolta az Európai Bíróság jogértelmezésen keresztül megvalósuló beavatkozása. A bírósági nézőpontot determinálta a szabályok Unión belüli egységes és hatékony alkalmazásának követelménye, amelynek eredményeként a tagállamok közpolitikai partikularizmusa ellenőrzés alá került, és visszaszorították az egyoldalú, a piaci integrációt károsító tagállami fellépést. A belső piac azonban nem egy politikai légüres térben működik és a politika eszközeivel irányítható. Az európai piaci integráció folyamatában a tagállamok a politikai kulcsszereplők, és az integráció folyamatának irányát és korlátait az ő kifejezett érdekeik határozzák meg, amelyeket természetesen a politikai térben újratárgyalnak. A Szerződésnek az alapvető szabadságokra vonatkozó rendelkezései kapcsán az Európai Bíróságnak a belső piac politikai beágyazottságával és a tagállamoknak a kiemelt érdek-jogosulti szerepével folyamatosan tisztában kell lennie. Az Európai Bíróság belső piaci szabad-

kontra Spanyolország ügyben hozott határozatát, EU:C:2014:218 és a C-543/08. sz. ügyben 2010. november 11-én hozott Bizottság kontra Portugália hozott határozatát, EU:C:2010:669.

${ }^{131}$ Lásd DAVIEs (129. lj.) 24. és Alexandre SAYDÉ: „Freedom as a source of constraint: expanding market discipline through free movement" in Panos Koutrakos - Jukka SNELl (szerk.): Research handbook on the law of the EU's internal market (Cheltenham: Edward Elgar Publishing 2017) 29-53. https://doi.org/10.4337/9781783478101.00008. Davies álláspontja kapcsán azt azért meg kell jegyeznünk, hogy a versenykorlátozó hatás bizonyítása sem egyszerü feladat.

${ }^{132}$ Lásd Davies (129. lj.) 21. A gazdasági és pénzügyi válság a gazdasági és szociális szférába való erőteljesebb tagállami beavatkozást tette szükségszerűvé. A bankmentő csomagok és a reálgazdaság megmentése elsősorban versenyjogi (állami támogatási) eszközökkel zajlott, és kevésbé volt hatással a négy gazdasági szabadsági bírói jogértelmezésére. Az Európai Bíróság leginkább a hitelválság fogyasztóvédelmi jogi síkján szembesült a hozzá felgyűrűző devizahiteles problémával, amelyet a fogyasztókkal kötött szerződésekre alkalmazott tisztességtelen feltételekről szóló 93/13/EGK tanácsi irányelv (HL 1993, L 95, 29.) értelmezése szolgált. A Bíróság legfontosabb döntései a Gazdasági és Monetáris Unió szabályainak értelmezése és nem a négy gazdasági szabadság értelmezése kapcsán születtek. Erről az Európai Bíróság egykori elnöke az alábbi elemzésében ír: https://www.europeanlawinstitute.eu/fileadmin/user_upload/p_elVGeneral_Assembly/2012/Keynote_Skouris_ Vassilios.pdf. A szociális integráció és tagállami érdekek viszonyáról lásd bővebben HUNGLER Sára: „Local Interests and Social Integration in Europe” in Marton VARJU (szerk.): Between Compliance and Particularism: Member State Interests and European Union Law (Cham: Springer 2019) 255-281. 
ságokra vonatkozó joggyakorlata látszólag nem vesz tudomást a tagállamok szerepéről, és azokról a belső piaci jogi korlátokról sem, amelyek a tagállamok számára fennálló közpolitikai és szabályozási autonómiából adódnak. A Bíróság túlzottan kiterjesztően értelmezte az alapvető szabadságok hatályát, és ezzel jelentős terheket rótt a tagállamokra, hogy a legitim közpolitikai célokból megszületett korlátozó intézkedéseiket igazolják. Ezen túl a joggyakorlat koherenciájának hiányosságai a tagállamok számára megnehezítette, hogy az EU-joggyakorlattal összhangban álló nemzeti közpolitikákat tervezzenek meg, főként azon tárgykörökben, amelyekben komplex közpolitikai fellépés szükséges.

Úgy tủnik, hogy az Európai Bíróság nehezen tudja megvonni azt a (finom) jogi határvonalat, amely kétféle partikularizmus között áll fenn. Az egyik, amely aláássa a belső piacból származó kollektív előnyök realizálását az összes tagállam közössége körében, a másik pedig teret ad az európai projekttel koherens legitim nemzeti érdek biztosításának, és amely kollektív erőfeszítésen és fellépésen alapul. 